Review Article

\title{
Medicinal Plants Used for Treatment of Diarrhoeal Related Diseases in Ethiopia
}

\author{
Bizuneh Woldeab, ${ }^{1}$ Reta Regassa, ${ }^{2}$ Tibebu Alemu $\mathbb{D}^{1},{ }^{1}$ and Moa Megersa ${ }^{1}{ }^{1}$ \\ ${ }^{1}$ Department of Environmental Health Science and Technology, Jimma University, P.O. Box 378, Jimma, Ethiopia \\ ${ }^{2}$ Department of Biology, Hawassa College of Teacher Education, P.O. Box 115, Hawassa, Ethiopia \\ Correspondence should be addressed to Moa Megersa; moamegersa78@gmail.com
}

Received 28 October 2017; Revised 26 December 2017; Accepted 12 February 2018; Published 18 March 2018

Academic Editor: Sandy van Vuuren

Copyright (c) 2018 Bizuneh Woldeab et al. This is an open access article distributed under the Creative Commons Attribution License, which permits unrestricted use, distribution, and reproduction in any medium, provided the original work is properly cited.

\begin{abstract}
This paper presents a review of relevant antidiarrhoeal medicinal plants based on the fundamental knowledge accumulated by indigenous people of Ethiopia. The review includes an inventory carried out on the phytochemical and pharmacological analysis of plant species used in the treatments of diarrhoeal diseases. This study is based on a review of the literature published in scientific journals, books, theses, proceedings, and reports. A total of 132 medicinal plants used by local people of Ethiopia are reported in the reviewed literature. Herbs (43.6\%) were the primary source of medicinal plants, followed by trees (27\%). Some findings include the predominance of leaf material used (78\%), as well as the frequent use of crushing of the plant parts (38\%) as a mode of preparation. This study demonstrates the importance of traditional medicines in the treatment of basic human ailments such as diarrhoeal diseases in Ethiopia. Baseline information gaps were observed in different regions of Ethiopia. Thus, documentation of the knowledge held by other regions of Ethiopia that have so far received less attention and urban ethnobotany is recommended for future ethnobotanical studies. In addition, phytochemical studies are recommended mainly on frequently utilized medicinal plants for treatment of diarrhoeal diseases which can serve as a basis for future investigation of modern drug development. Although societies in Ethiopia have long used medicinal plants for diarrhoeal diseases treatment, it is also a good practice to perform toxicological tests.
\end{abstract}

\section{Introduction}

Diarrhoea is a leading killer of children, accounting for nine percent of all deaths among children under age of five worldwide in 2015 [1]. Sub-Saharan Africa and southern Asia were the regions with the highest child death rates due to diarrhoea in 2015 [2]. In these regions, children under five experience 3.2 to 12 episodes of diarrhoea every year [2]. It is also reported that millions of people were at risk of diarrhoea in Ethiopia, where acute watery diarrhoea broke out in crowded and unsanitary conditions of urban and rural areas in 2009 [3]. To fight this problem, the World Health Organization (WHO) has initiated a diarrhoea disease control program to study traditional medicine practices and prevention approaches [4]. This may have valuable advantages in reducing mortality rate in developing countries due to diarrhoea.

In Ethiopia, plants have been used as a source of medicine from time immemorial to treat different ailments and traditional medicine is an integral part of Ethiopian culture [5]. Traditional remedies are the most important and sometimes the only source of therapeutics for nearly $80 \%$ of the Ethiopian population and $95 \%$ of the preparations are of plant origin [6]. The widespread use of traditional medicine in communities of Ethiopia could be attributed to cultural acceptability, efficacy, physical accessibility, and economic affordability as compared to modern diarrhoeal medicine [6]. Study on traditional remedies in Ethiopia demonstrates that diarrhoea is one of the most prominent diseases treated by traditional medicines [7-9].

Although there are a range of medicinal plants with antidiarrhoeal properties that have been widely used by local communities of Ethiopia, the effectiveness of many of these antidiarrhoeal traditional medicines has not been scientifically evaluated [10]. Recently, a few of these medicinal plants have attracted considerable attention and studies 


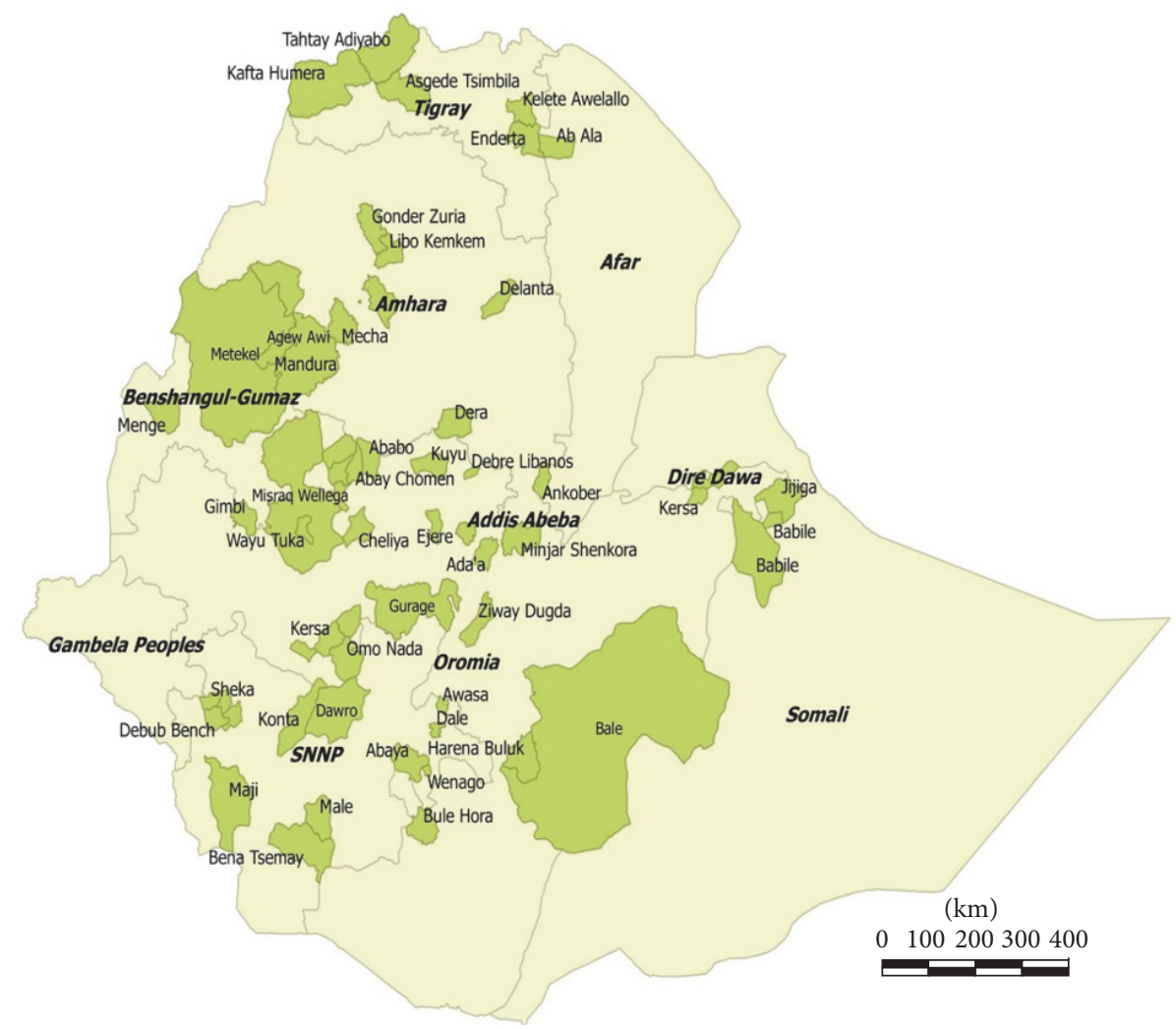

Study areas

FIgURE 1: Location of study sites in Ethiopia.

being conducted to scientifically evaluate their antidiarrhoeal activities. For instance, the antidiarrhoeal activities of Calpurnia aurea [11], Cordia africana [12], Indigofera spicata [13], Lepidium sativum [14], Stereospermum kunthianum [15], Vernonia amygdalina [16], and Zehneria scabra [17] have been investigated on experimental animals.

It has been reported in various studies $[9,18,19]$ that the knowledge on medicinal plants is getting lost due to the lack of interest by the younger generation. Since the knowledge of traditional medicine is transferred orally from generation to generation, the basic information about part of the plants used, drug preparation methods, the diseases treated, and others may be lost and discarded amidst the knowledge transfer process. Therefore, documentation of these medicinal plants is important in order to identify candidate species for the invention of therapeutic drugs. Thus, this review is initiated to document traditional uses of medicinal plants to treat diarrhoeal diseases in Ethiopia, to provide comprehensive documentation, to identify research gaps, and to suggest perspectives for future research.

\section{Methods}

The traditional uses of medicinal plants used to treat diarrhoeal diseases in Ethiopia were collected from available literature published in scientific journals, books, theses, proceedings, and reports. Literature was searched in different electronic databases (Web of Science, MEDLINE, Science Direct, and Google Scholar) and accessed between April 2016 and September 2017 using specific search terms such as "medicinal plants", "traditional medicines", and "Ethiopia or Indigenous people". After identifying potential literatures, we searched if there is a report of medicinal plants used for treatment of diarrhoea in the region where the study was carried out. Data collected from the literature includes mode of preparation and administration of the species, plant parts used, additives, condition, and dosages used. Moreover, literature search was also done to document the biological and pharmacological activities of the mostly used plant species for treatment of diarrhoea.

We reviewed a total of 58 publications that provided information about the use of medicinal plant species to treat diarrhoeal diseases in Ethiopia (Figure 1). There are papers reported about the use of medicinal plant species from all regions of Ethiopia published between 1965 and 2017.

\section{Medicinal Plants Diversity}

This study recorded one hundred thirty-two plant species as useful in traditionally managing diarrhoeal diseases in Ethiopia (Table 1). These medicinal plants were distributed among 52 families and 113 genera. Most of medicinal plants, 


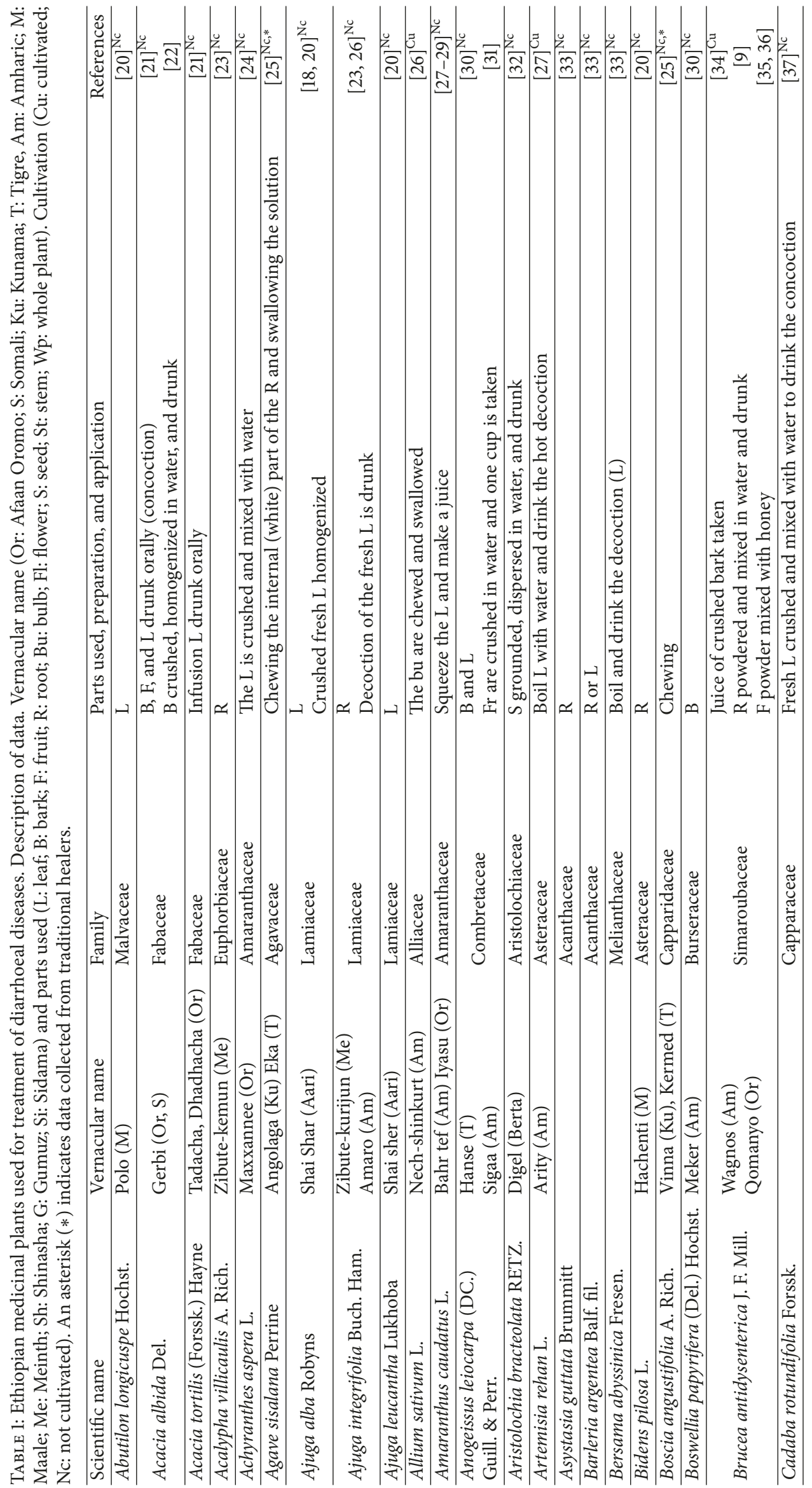




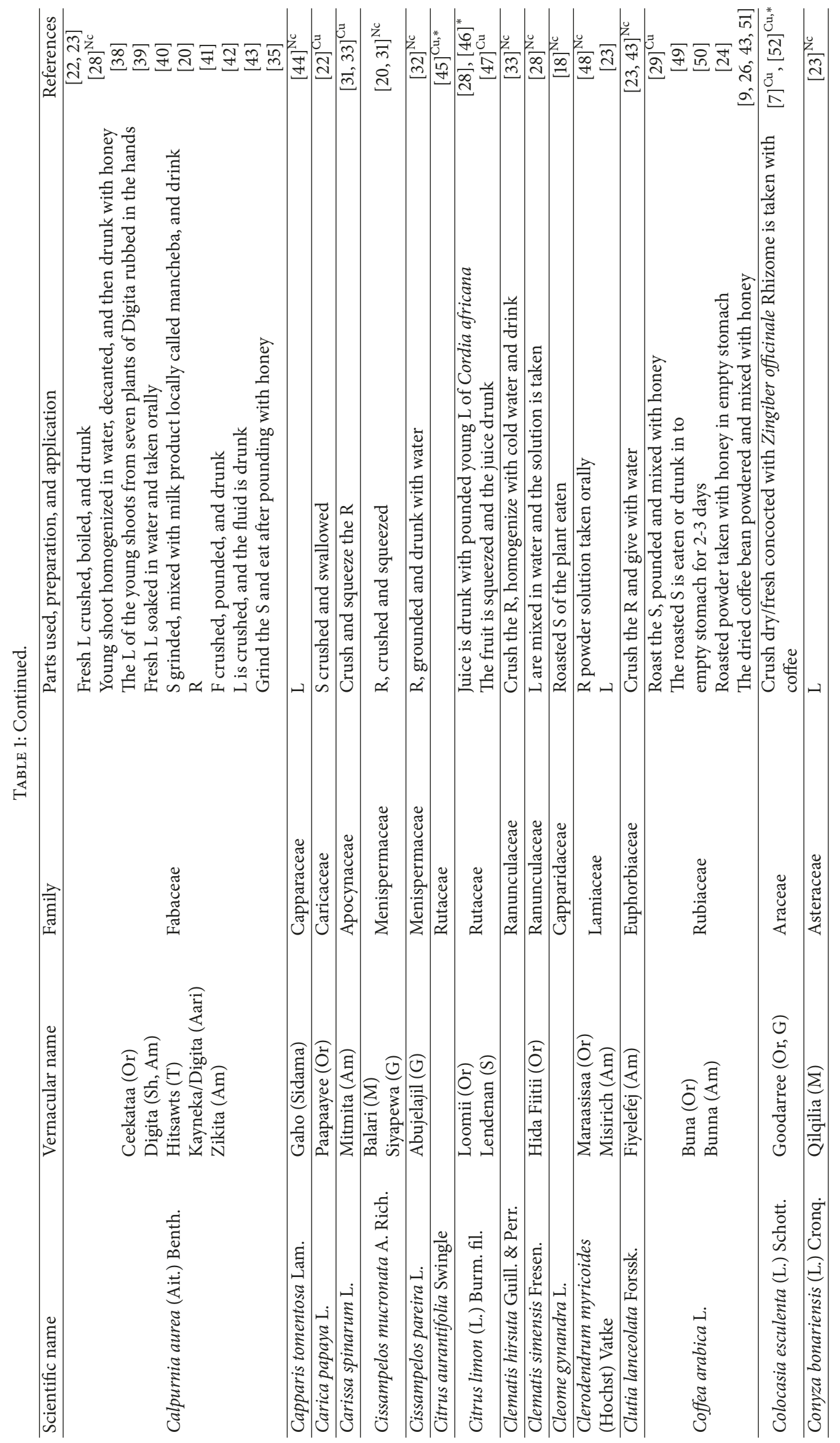




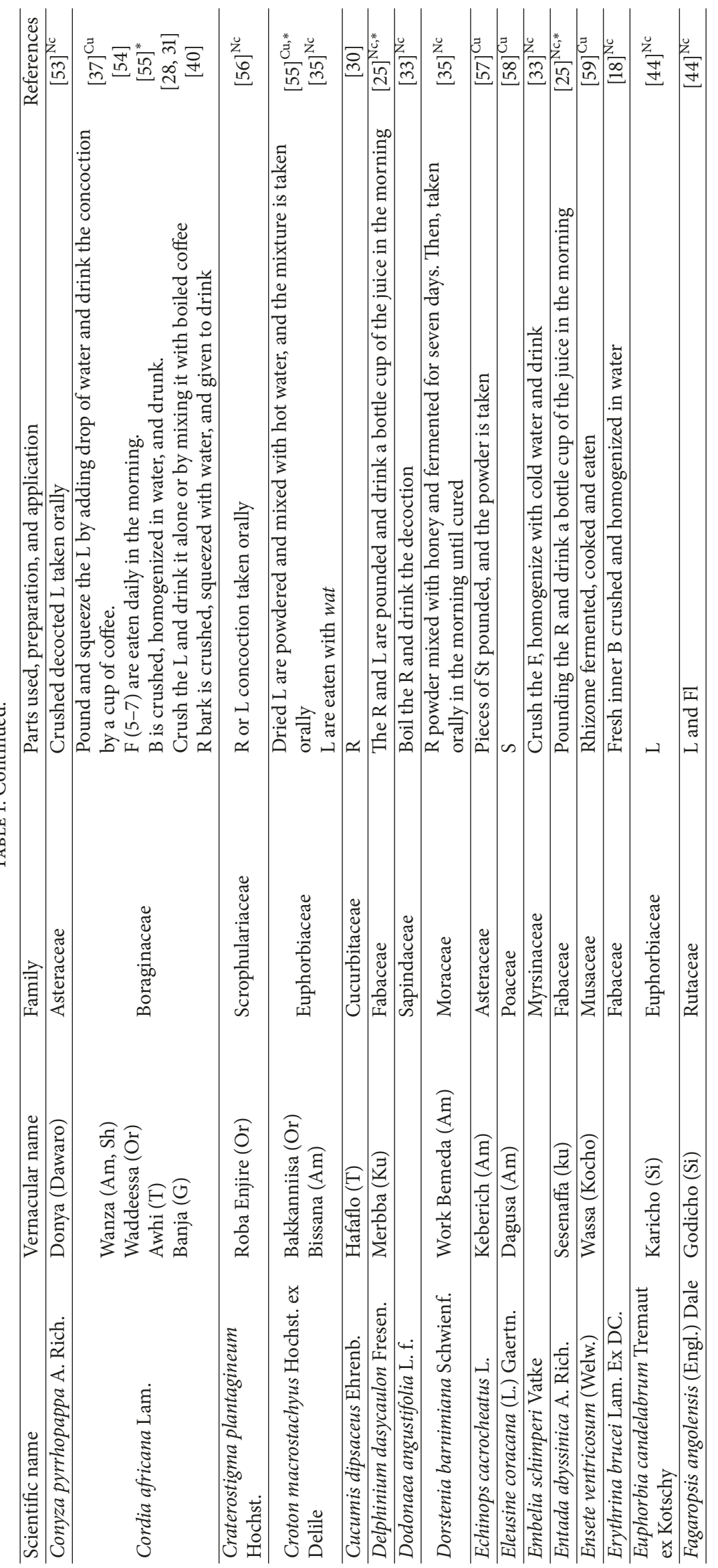




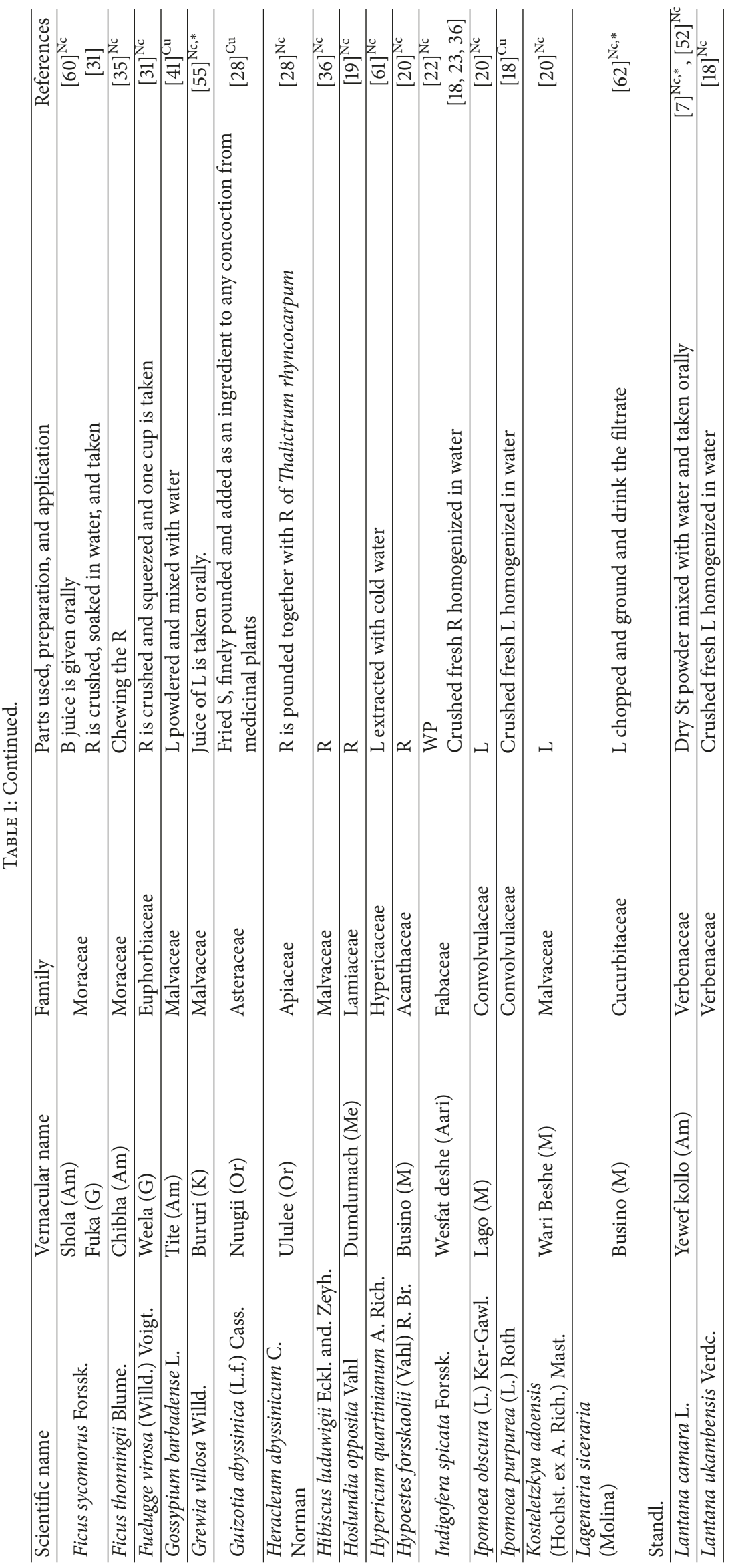




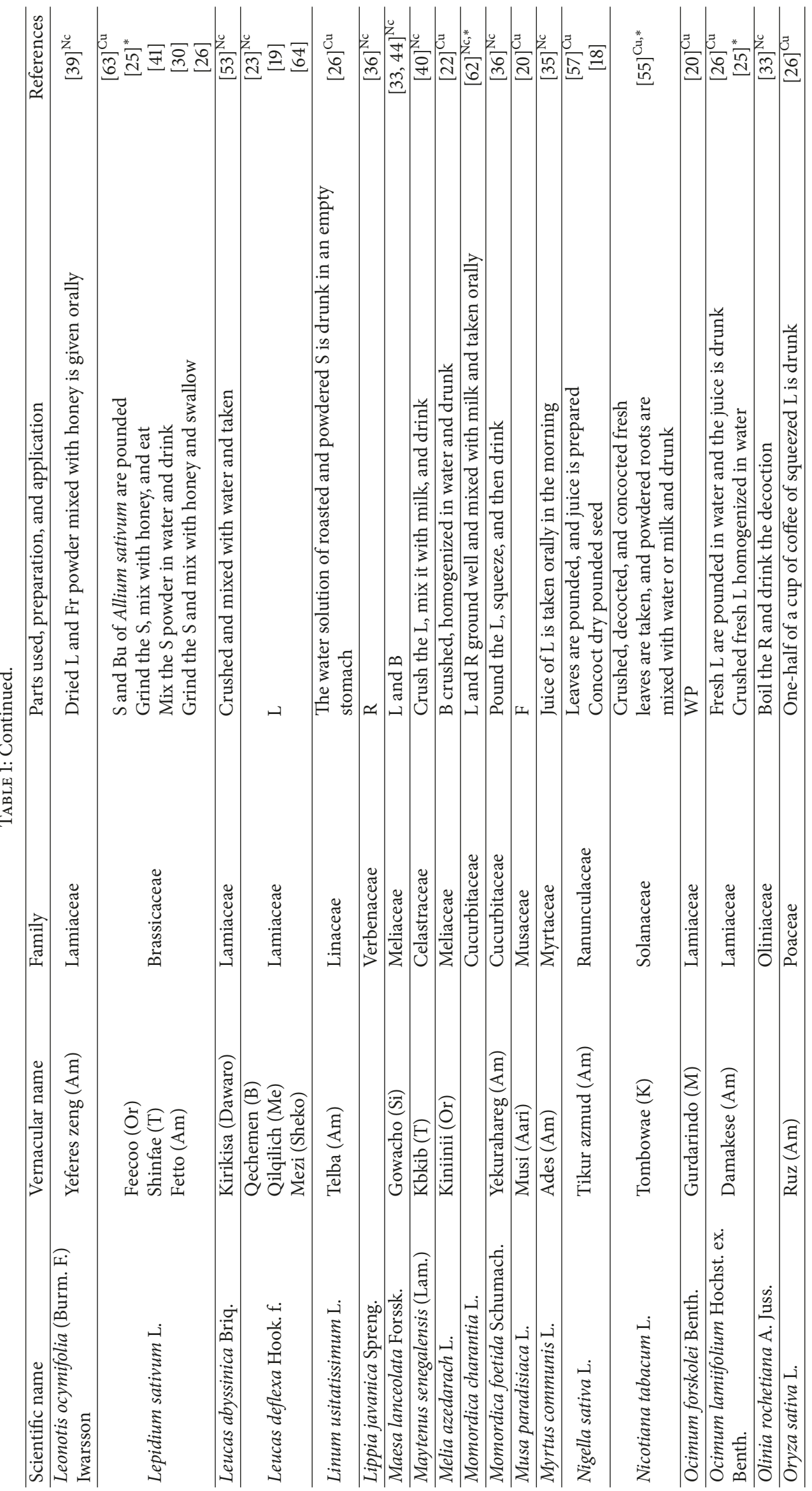




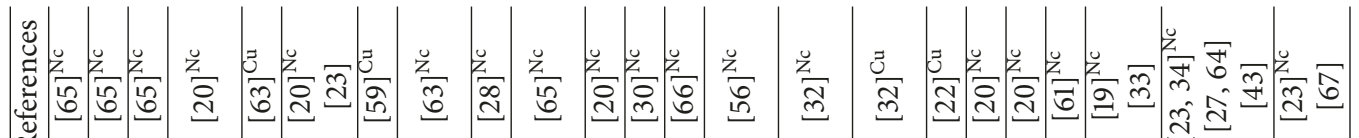

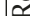

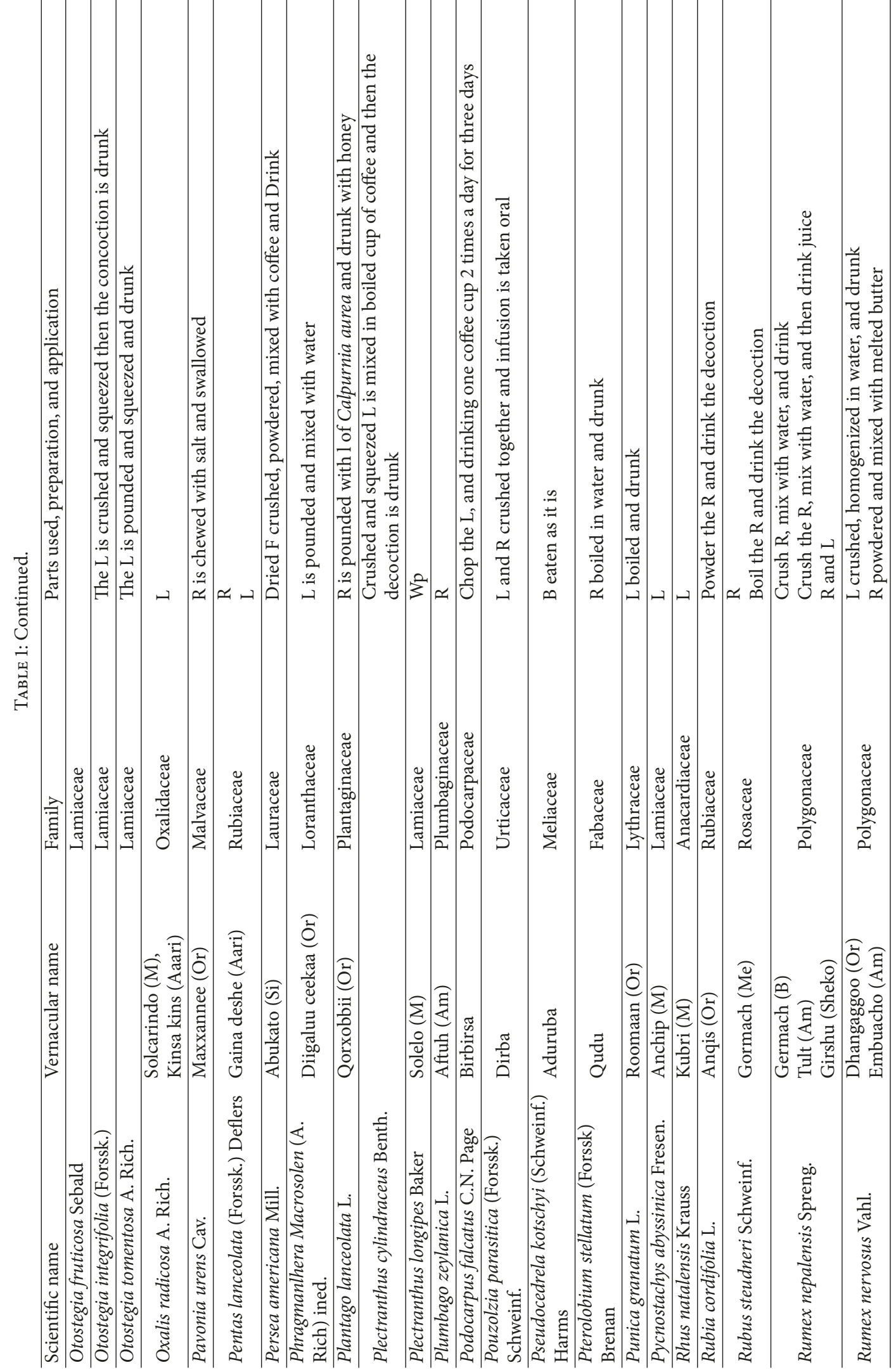




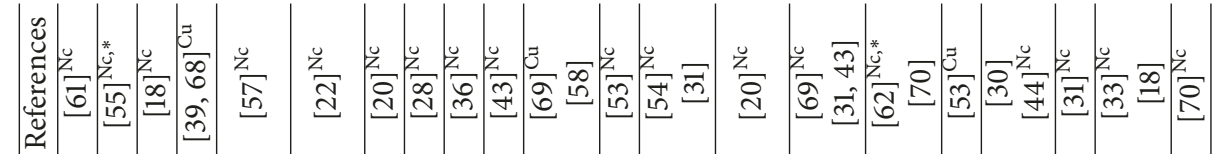

递

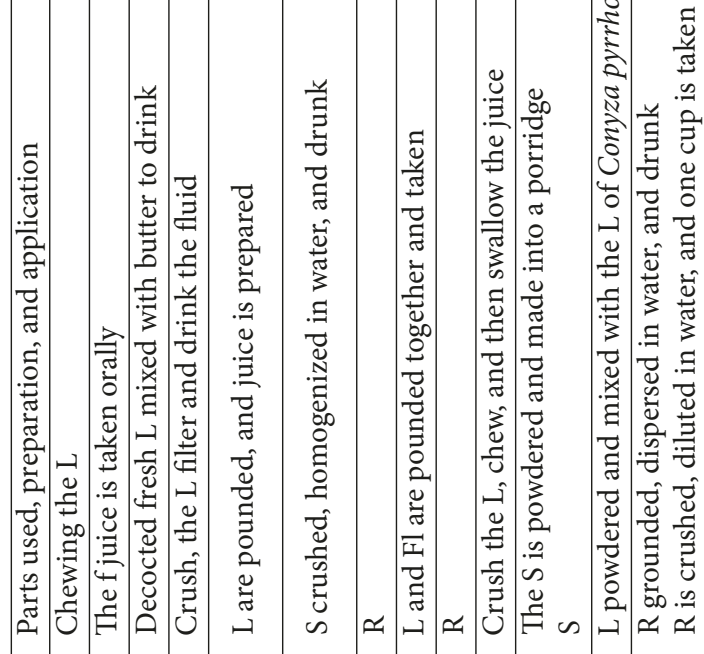

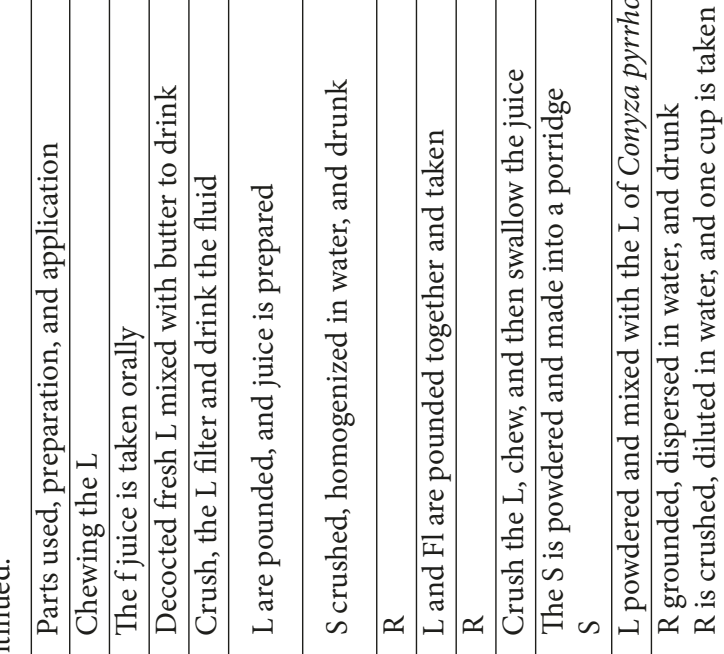

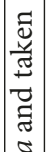

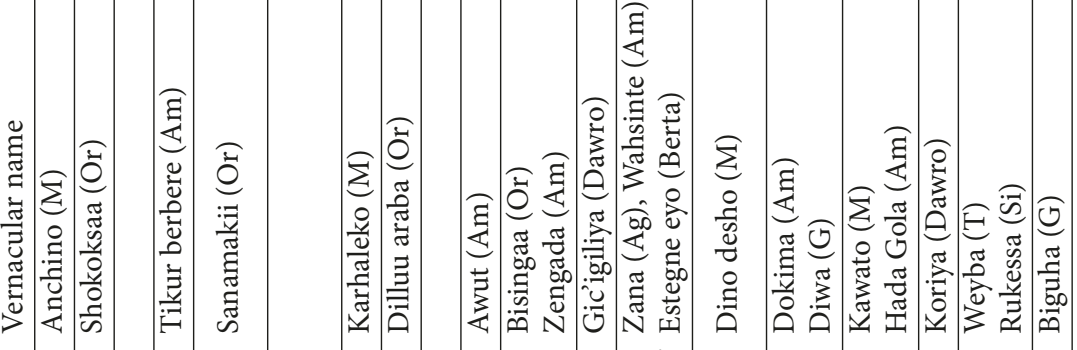

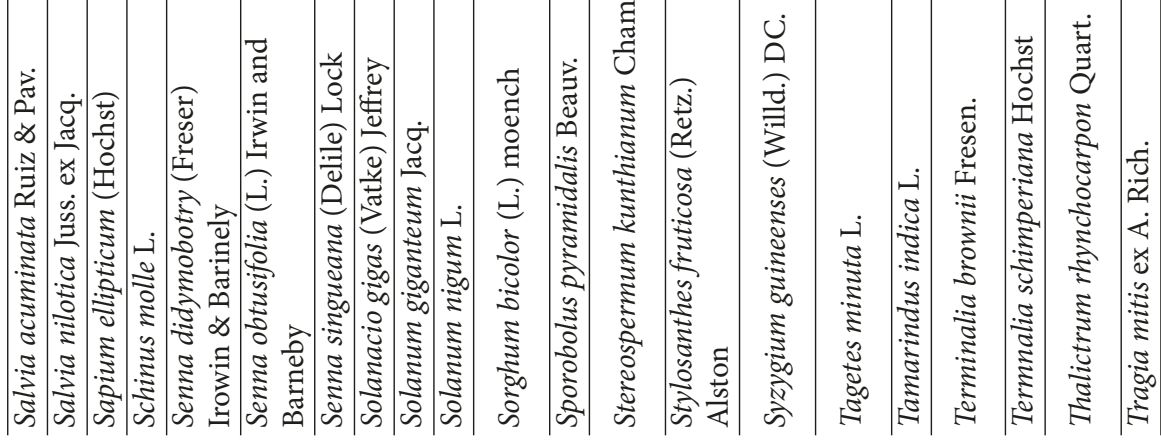




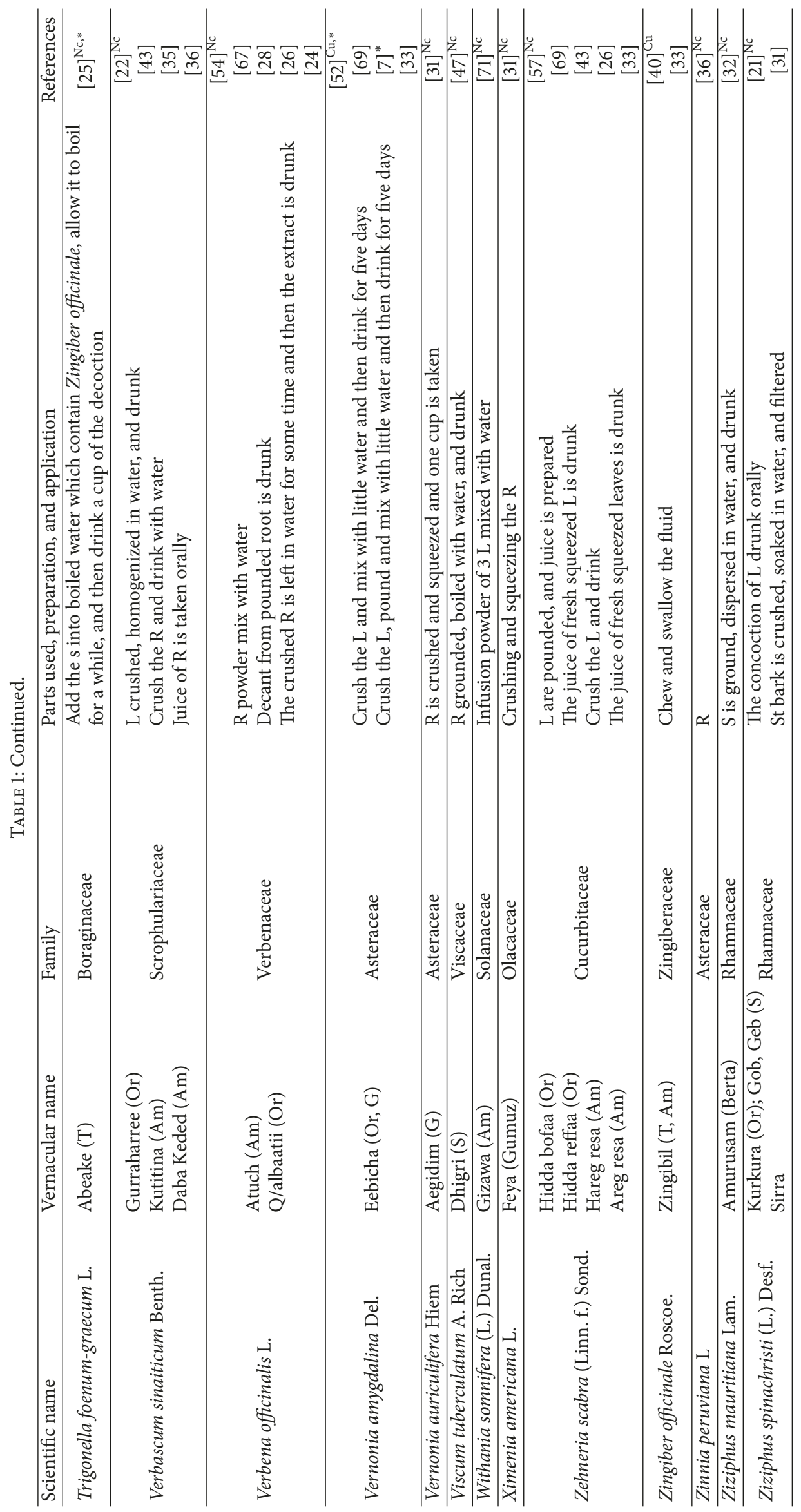


TABLE 2: Taxonomic diversity of medicinal plants in the study area.

\begin{tabular}{lcccc}
\hline Family & Number of genera & Percentage & Number of species & Percentage of species \\
\hline Fabaceae & 10 & 9.0 & 12 & 9.1 \\
Lamiaceae & 7 & 6.2 & 12 & 9.1 \\
Asteraceae & 8 & 7.1 & 10 & 7.5 \\
Euphorbiaceae & 7 & 6.2 & 7 & 5.3 \\
Cucurbitaceae & 3 & 2.6 & 4 & 3.0 \\
Malvaceae & 4 & 3.5 & 4 & 3.0 \\
Poaceae & 4 & 3.5 & 4 & 3.0 \\
Ranunculaceae & 3 & 2.6 & 4 & 3.0 \\
Solanaceae & 3 & 2.6 & 4 & 3.0 \\
Verbenaceae & 3 & 2.6 & 3 & 2.3 \\
Rubiaceae & 3 & 2.6 & 3 & 3 \\
Rutaceae & 2 & 1.7 & 3.3 & 2.3 \\
Moraceae & 2 & 1.7 & 58 & 13.0 \\
Other 39 families & 54 & 47.7 & 132 & 100.0 \\
Total & 113 & 100.0 & 4 & \\
\hline
\end{tabular}

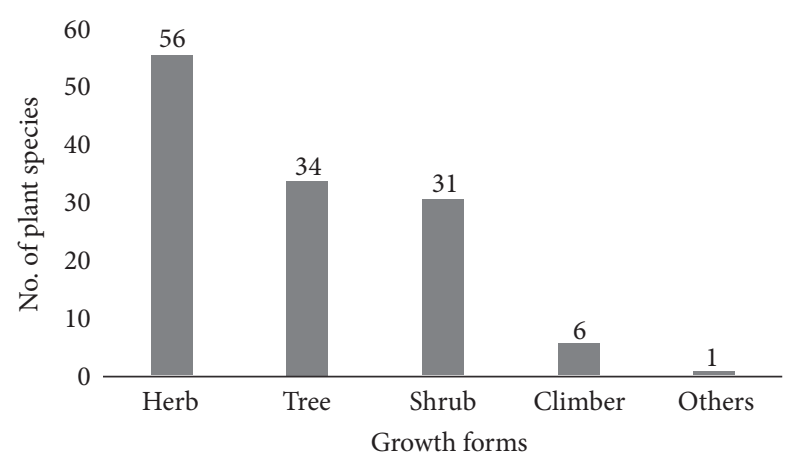

FIGURE 2: Growth forms (habits) of medicinal plants.

74 (56\%), used in Ethiopia for diarrhoeal treatment are from 29 families (Table 2). Plant families with the highest number of medicinal plants in Ethiopia used for diarrhoeal diseases treatment were Fabaceae and Lamiaceae (12 species each), followed by Asteraceae (10 species), Euphorbiaceae (7 species), Verbenaceae, Solanaceae Malvaceae, Ranunculaceae, Poaceae, and Cucurbitaceae (4 species each). Fabaceae, Lamiaceae, and Asteraceae families have the highest number of species used as herbal medicines. The rest of the families were represented by one, two, or three species each (Table 2). The genus with the highest number of species was Ajuga with three species.

3.1. Growth Forms and Parts Used. The result of growth form analysis of medicinal plants shows that herbs constitute the highest proportion being represented by 56 (43.6\%) species, while there were 34 (27\%) tree species, 31 (20.6\%) shrubs, and $6(2 \%)$ climbers (Figure 2). Almost all plant parts, the roots, rhizomes, stem, bark, leaves, flowers, fruits, young shoots, and whole plants, were used to prepare different remedies (Table 1). The most frequently used plant parts were leaves (78\%), followed by roots (60\%), and seeds (29\%), and others constitute $20 \%$ (Figure 3 ).
TABLE 3: Method of preparation of traditional medicine in Ethiopia.

\begin{tabular}{lcc}
\hline Method of preparation & Number of preparations & Percentage \\
\hline Crushing & 53 & 38.2 \\
Decoction & 30 & 21.5 \\
Powdered & 14 & 10.1 \\
Chewing & 7 & 5.0 \\
Concoction & 5 & 3.6 \\
Others & 30 & 21.5 \\
\hline
\end{tabular}

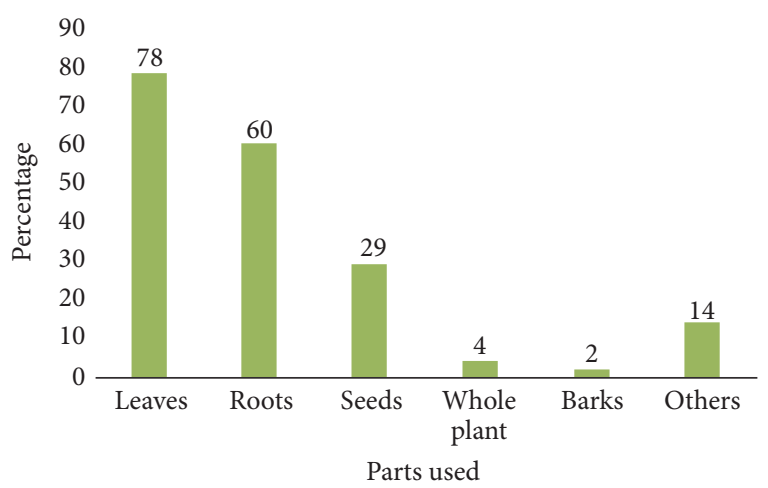

FIgURE 3: Plant parts used for the treatment of diarrhoeal diseases in Ethiopia.

3.2. Methods of Preparation of Traditional Medicine. Most of the medicinal plant preparation involved the use of single plant species or a single plant part (76\%), whereas the preparation via mixing different plants or plant parts (24\%) is rarely encountered in Ethiopia. In Ethiopia, the most common methods of preparation of traditional medicine from plant materials are crushing (38\%), followed by decoction $(21 \%)$ and others (Table 3).

3.3. Condition, Additives, and Dosages of Medicinal Plants. Most of the remedies (58\%) used in Ethiopia for treatment of 
diarrhoeal diseases are prepared from fresh parts of medicinal plants followed by drying form $27 \%$ and $15 \%$ prepared either from dry or fresh plant parts. Various additives are used during administration of traditional medicine. Additives like honey $(48 \%)$, salt $(13 \%)$, sugar (13\%), local beer (3\%), milk $(16 \%)$, and butter $(6.5 \%)$ are used with traditional medicine to increase the flavor, taste, and general suitability of orally administered remedies.

People living in rural areas of Ethiopia use various ways of measuring dosage which are generally categorized under three major classes. One is dosage used for those medicinal plants which are expected to be highly toxic. For such medicines, the measurement can be undertaken by little finger index and very little amount of the prepared medicine taken by half a coffee cup. For example, medicines prepared from Cordia africana, Calpurnia aurea, Verbena officinalis, and Brucea antidysenterica are toxic if overdosed. The second is the dosage used for medicinal plants which can have little effect on human health if overdosed. The dosage is measured by hand palm and taken by bottle or locally made material from Lagenaria siceraria. Examples of species include Delphinium dasycaulon and Entada abyssinica. In the third case, there are medicinal plants that do not have any observable side effect. Medicines prepared from Zingiber officinale, Coffea arabica, Syzygium guineense, Guizotia abyssinica, and Citrus limon can be taken according to the existing traditional practice of communities and/or personal preference.

3.4. Frequently Reported Medicinal Plants. Among the most commonly used plants were Calpurnia aurea, Coffea arabica, Cordia africana, Rumex nepalensis, Zehneria scabra, Verbena officinalis, Verbascum sinaiticum, Amaranthus caudatus, Vernonia amygdalina, Stereospermum kunthianum, Lepidium sativum, Indigofera spicata, Syzygium guineense, Leucas deflexa, Citrus limon, and Brucea antidysenterica are some to mention.

3.5. Phytochemical and Pharmacological Studies of Mostly Reported Medicinal Plants. The most frequent approach to species selection for phytochemical, pharmacological, or antimicrobial analysis is by reviewing the ethnobotanical literature [72]. In this approach, various modern drugs were extracted from traditional medicinal plants using plant materials [73]. Plant-based traditional medicine is still playing a vital role in the development and advancement of modern studies by serving as a starting point for the development of novelties in drug discovery [74]. The presence of active ingredients such as flavonoids, terpenoids, steroids, phenolic compounds, and alkaloids in herbal medicines has been reported to have antimicrobial activity and directly linked to their ability to prevent or treat ailments such as diarrhoeal diseases $[75,76]$. Phytochemical analysis of plant preparations and the identification of active components therein is also helpful to explain the mechanism of antidiarrhoeal activity [10]. For instance, polyphenols and tannins provide strength to intestinal mucosa, decrease intestinal secretion, and promote balance in water transportation across the

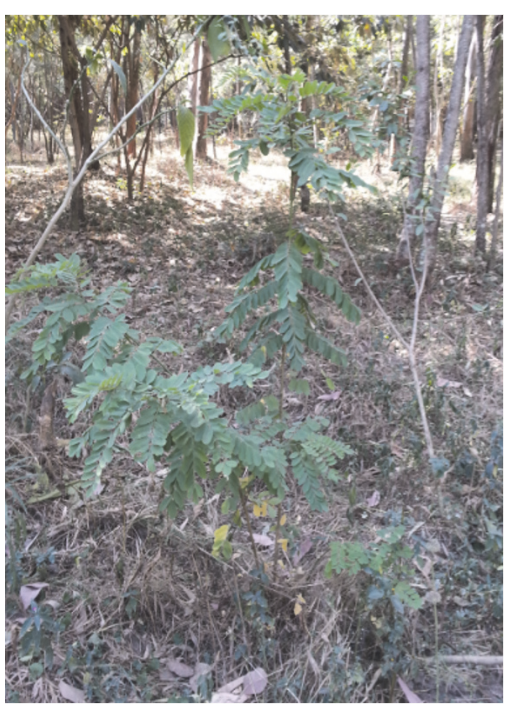

Figure 4: C. aurea (Courtesy: [Regassa, Hawassa, Ethiopia, 2016]).

mucosal cells [77]. Flavonoids and saponins inhibit the release of prostaglandins, autacoids, and contractions caused by spasmogens as well as motility and hydroelectrolytic secretions [78]. The phytochemical analysis of mostly cited medicinal plants used for treatment of diarrhoeal diseases in Ethiopia will be discussed below. Few of these plants have been validated as treatments for diarrhoea based on their ability to prevent diarrhoeal symptoms induced in experimental animals.

3.5.1. Calpurnia aurea (Ait.) Benth. It is shrub or small tree commonly growing up to $5 \mathrm{~m}$ in bushlands and occasionally up to $10 \mathrm{~m}$ in forests of Ethiopia. The plant grows in different habitats, such as grazing lands, roadsides, and homegardens $[9,18]$. C. aurea is widespread throughout the highlands from 1400 to $2500 \mathrm{~m}$ where rainfall is from 1000 to $2000 \mathrm{~mm}$ per year [79]. Trees are found in flower throughout the year but most abundantly after the small rains in May [79]. The leaves of $C$. aurea (Figure 4) are used traditionally in many parts of Ethiopia to treat diarrhoeal diseases. The use of $C$. aurea for diarrhoeal diseases by local people of Ethiopia was reported 14 times by researchers. Methanol extracts of leaf revealed the presence of alkaloids, tannins, flavonoids, and saponins [11]. Plants species possessing alkaloids, tannins, flavonoids, steroids, and terpenoids exhibit antidiarrhoeal activity [80]. Alkaloids demonstrated inhibitory effect on Nitric oxide synthesis [81]. Tannins and flavonoids have been reported to have antidiarrhoeal activity through inhibition of intestinal motility [82] and hydroelectrolyte secretion [83]. The leaf extracts of $C$. aurea have exhibited dose (100-400 mg/kg) dependent inhibition of castor oil induced diarrhoea on experimental mice like loperamide [11]. More interestingly, studies also confirmed that extracts from the species have broad spectrum antibacterial activity [84]. Being broad spectrum is advantageous in reducing diarrhoea as there are various causative agents of the disease. 


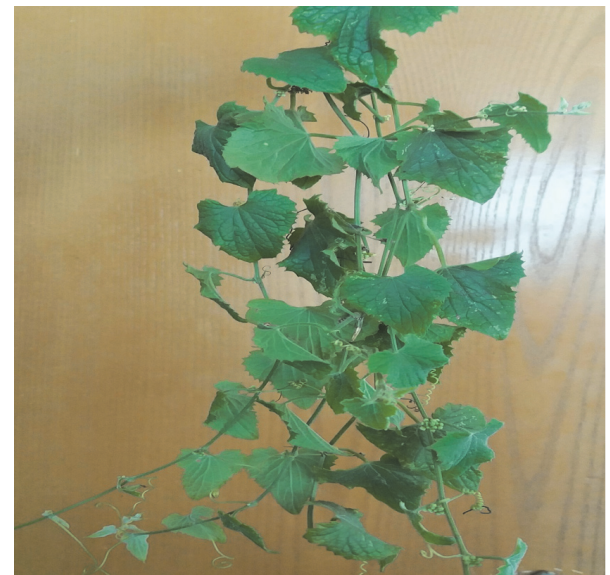

Figure 5: Z. scabra (Courtesy: [Woldeab, Jimma, Ethiopia, 2017]).

3.5.2. Zehneria scabra (Linn. f.) Sond. Z. scabra is one of the commonly used medicinal plants in Ethiopian traditional medicine practices (Figure 5). Local people in Ethiopia use the leaves of the plant to get relief from diarrhoea [43]. The plant is also used for the treatment of wound, alopecia, and eczema in folk medicines [85]. The phytochemical study conducted by [17] showed the presence of tannins, saponins, anthraquinones, $\mathrm{O}$-anthraquinones, and phenols in the crude extract of leaves of $Z$. scabra. The phytochemical study of root extracts of $Z$. scabra by [86] also revealed the presence of Gypenoside. China pharmaceutical company manufactures Gypenoside tablets; it is used as a supplemental medicine for treating various diseases. The methanolic extracts of $Z$. scabra showed antidiarrhoeal activity in mice [17]. Studies also report that ethanol, methanol, ethyl acetate, and aqueous extracts of $Z$. scabra show maximum zone of inhibition for standard strains of Staphylococcus aureus [86].

3.5.3. Stereospermum kunthianum Cham. It is a small tree occurring at medium to low altitudes, frequently on rocky outcrops and hillsides. It also occurs in open woodlands and at margins of evergreen forests [87] and is found from 700 to $2000 \mathrm{~m}$ in areas with an annual rainfall range between 700 and $1800 \mathrm{~mm}$ per year [79]. Flowering most abundantly after the small rains in April and May, some trees can be found with flowers any time from September up to May [79]. S. kunthianum is only found in the wild and increasingly becoming difficult to harvest due to high scarcity [54]. The root and bark of the plant $S$. kunthianum are used in diarrhoea treatment in Ethiopia [31,35]. Preliminary phytochemical screening of the leaves extract of $S$. kunthianum reveals the presence of sterols/triterpenes, saponins, tannins, coumarins, and free carboxylic group [88]. The methanolic extracts from this plant species exhibited antidiarrhoeal activity on mice. The effect is comparable to loperamide, which is presently one of the most widely used antidiarrhoeal drugs [88]. The antidiarrhoeal effect of a flavonoid isolated from the stem bark aqueous extract of $S$. kunthianum is investigated using rodent models of castor oil-induced gastrointestinal motility and castor oil-induced diarrhoea [15]. The result

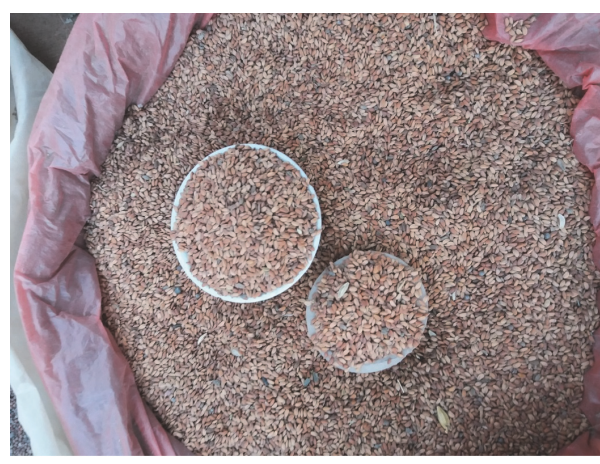

Figure 6: L. sativum seeds (Courtesy: [Regassa, Hawassa, Ethiopia, 2016]).

indicates that pretreatment with dimethoxyflavone causes a delay in the onset of diarrhoea, reduction in the frequency, and weight of wet stools [15]. The result from this study suggests that the antidiarrhoeal activity of dimethoxyflavone from S. kunthianum castor oil-induced diarrhoea in mice is probably due to antielectrolyte permeability action [15]. Toxicity studies of the aqueous extract of $S$. kunthianum stem bark show that the extract has a wide safety margin [89].

3.5.4. Lepidium sativum $L$. It occurs in all regions of Ethiopia at altitudes between 750 and $2900 \mathrm{~m}$ [90]. L. sativum is not widely cultivated; instead it grows with other crops, particularly Eragrostis tef (Zucc.) Trotter and is available in all local markets [79]. In different regions of Ethiopia, L. sativum seeds (Figure 6) are used commonly to treat abdominal discomfort, such as dysentery and diarrhoea $[9,42]$. A study conducted by [91] indicated antidiarrhoeal effect of alcoholic and aqueous extract of L. sativum seeds in three animal models (castor oil induced diarrhoea in rats, prostaglandin induced enteropooling in rats, and charcoal meal test in mice) of diarrhoea. Furthermore, the study found aqueous extract to be more potent than alcoholic extract. L. sativum has been used widely in different parts of the world for its wide therapeutic application [14]. The plant is well studied phytochemically with various active components, such as alkaloids, riboflavin, and ascorbic, linoleic, oleic, palmitic, and stearic acids [92]. Moreover, cucurbitacin has also been identified as plant constituent [93]. The plant has been shown to exhibit antidiarrhoeal and antispasmodic effects in rats, mediated through dual blockade of muscarinic receptors and $\mathrm{Ca}^{++}$channels [14]. The findings of [94] suggest that the aqueous methanol extracts of seeds of $L$. sativum exhibit antidiarrhoeal activity through activation of $\mathrm{K}^{+}$channels and inhibition of PDE enzyme in rabbit intestine.

3.5.5. Vernonia amygdalina Del. It is found in a wide range of bushlands, woodlands, and forest habitats between 500 and $2800 \mathrm{~m}$; it is also often found around home. Its rainfall range is from 750 to $2000 \mathrm{~mm}$ per year [95]. Flowering trees can be found from December to May, but the main flowering period is from January to February [79]. Some observations showed that the plant is widely available and frequently 


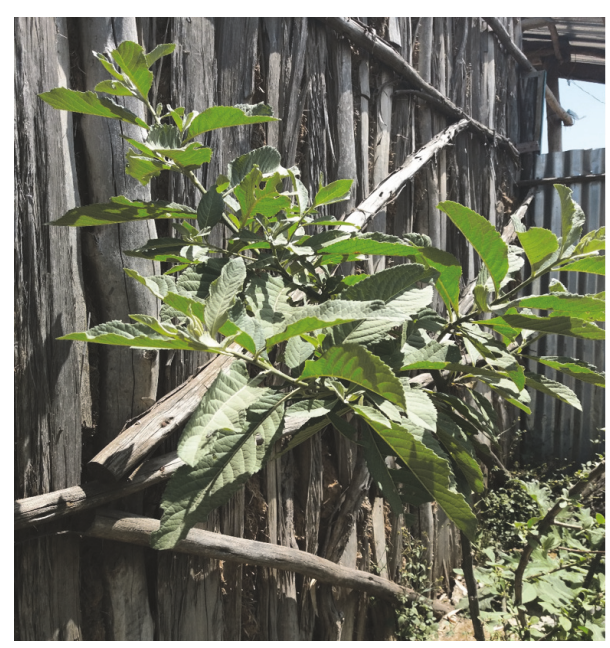

Figure 7: V. amygdalina (Courtesy: [Megersa, Gute, Ethiopia, 2013]).

growing in homegardens [7, 9, 17, 33, 69]. The leaves of $V$. amygdalina (Figure 7) are used in Ethiopian folk medicine to treat malaria [7, 9] and gastrointestinal disorders [28, 42, 58]. The leaf extract is reported to reduce the symptoms of castor oil-induced diarrhoea in rats and reduce gastrointestinal transit of a charcoal meal in mice [10]. Methanolic extract of $V$. amygdalina shows that the $400 \mathrm{mg} / \mathrm{kg}$ body weight administered orally to the experimental rats was effective in the reduction of the faecal spots [16]. A qualitative phytochemical analysis revealed the presence of some important active components such as saponins and alkaloids [16, 96], tannins [16], flavonoids [97], and glycosides [16]. Some of these components might be responsible for the antidiarrhoeal properties [96]. Therefore, this might indicate that the antidiarrhoeal activities are the most likely combined effect or a single effect [16]. Moreover, the other biomolecules may be neither synergistic nor antagonistic.

3.5.6. Cordia africana Lam. It is found in moist evergreen highlands and riverine forests of the northwest and southwest highlands and very common in western Ethiopia between 550 and $2600 \mathrm{~m}$ where the rainfall range is 700 to $2000 \mathrm{~mm}$ per year [79]. Some trees can be found in flower at any time of the year, but the main flowering period is from October to March [87]. C. africana is the most preferred plant by local people of Ethiopia for various uses, such as construction, timber production, charcoal, and medicine $[9,54,55]$. Due to its multipurpose uses, C. africana is becoming threatened, which is evidently shown by its scarce distribution in different areas of Ethiopia [9, 54, 98]. C. africana is one of indigenous tree species that have currently been given conservation priority by using in situ and ex situ conservation in the country [99].

In an ethnobotanical study, C. africana (Figure 8) is reported to be used in the management of diarrhoea in Shinasha, by Agew-Awi, Oromo, Tigray, and Amhara people in Ethiopia [28, 31, 37, 55]. The phytochemical analysis of methanolic root bark extracts of C. africana revealed that the plant material contains phenols, saponins, tannins,

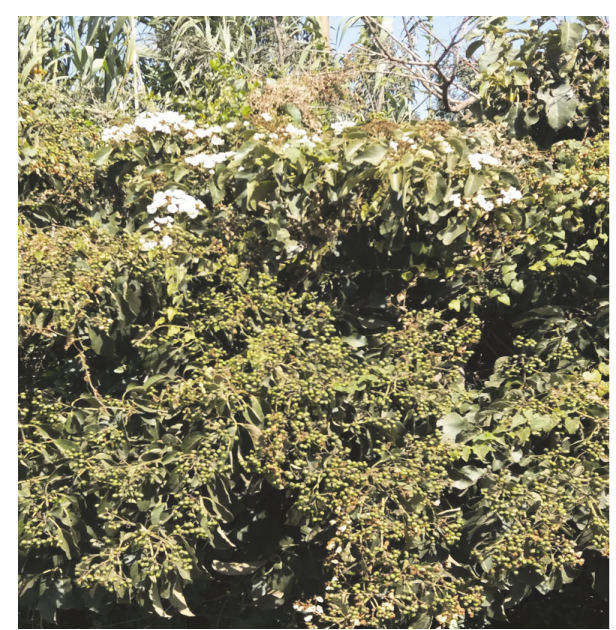

Figure 8: C. africana (Courtesy: [Megersa, Gute, Ethiopia, 2013]).

terpenoids, and flavonoids [100]. The mechanism of action of saponin for antidiarrhoeal effect is through the inhibition of histamine; terpenoids inhibit release of autacoids and prostaglandins; phenol makes intestinal mucosa more resistant [12]. There are considerable reports on C. africana studies showing the antidiarrhoeal effects on experimental animals $[12,101]$ For instance, the study conducted by [101] indicated the significant reduction of castor oil induced diarrhoea compared to loperamide. The study also revealed that the extract significantly reduced intestinal transit like that of atropine.

3.5.7. Indigofera spicata Forssk. I. spicata is traditionally used for the treatment of meningitis [18], diarrhoea [20, 23], stomach-ache [35], diabetes [9], and other health problems in Ethiopia. Phytochemical studies conducted on this plant species indicated the presence of alkaloids, flavonoids tannins, and steroids in this plant $[13,102]$. Steroids reported to enhance the absorption of hydroelectrolytes across the intestinal lumen [75]. In the castor oil induced diarrhoea in mice, the root extract of $I$. spicata inhibits frequency of defecation and fluid content of stool more likely in a dose dependent manner [13]. Moreover, the study found $53.51 \%$ inhibition of frequency of defecation which was equivalent to $51.02 \%$ of the positive control (atropine). The demonstrated biological antidiarrhoeal activity of crude root extracts of $I$. spicata could be due to the presence of these constituents [13]. Besides its use as antidiarrhoeal, usage of this plant raises the safety concern because the plant has showed effect on liver and cause abortion [103] and teratogenic effects in animals [104].

3.6. Prospects and Viewpoints. This review showed that local people in Ethiopia rely on traditional medicines to treat diarrhoeal diseases and are knowledgeable about the applications of medicinal plants. Many people in Ethiopia are still dependent on medicinal plants, at least for the treatment of basic human ailments. Diarrhoea is a major concern in Ethiopia and it is one of the basic human ailments frequently 
treated by medicinal plants in many regions of Ethiopia $[8,9$, 46]. The finding correlates strongly with observations made by [105] that diarrhoea is a major concern in Mozambique [106], in South Africa, and [76] in south-central Zimbabwe. Reports of similar medicinal applications of the documented plants in Ethiopia and the rest of the world indicate that these species are valuable sources of ethnomedicines.

The current review addresses the existence of traditional indigenous knowledge. This considerable indigenous knowledge, from the earliest times, is linked with the use of traditional medicine in many countries including Ethiopia [107]. Indigenous knowledge refers to the knowledge, innovations, and practices of indigenous and local communities around the world [108]. Thus, there is a growing appreciation of the value of traditional knowledge and its potential benefits to modern industry [108]. Many widely used products, such as plant-based medicines for human and livestock health, have been developed using indigenous traditional knowledge. It is, therefore, necessary to preserve this indigenous knowledge on traditional medicines by proper documentation, identification of plant species used, herbal preparation, and dosage. This review will assist future studies on the selection of herbal plants to evaluate for phytochemical safety and pharmaceutical efficacy.

Almost all ethnobotanical studies in Ethiopia have so far focused on medicinal plants used by rural communities. Urban ethnobotany is minimal or lacking as almost all studies gave with consideration to ethnobotanical studies in rural areas. Applied to the context of immigration, urban ethnobotany will offer the opportunity to evaluate ethnobotanical data within a larger, transnational framework by comparing plant knowledge and use by the same cultural group in its original and new environment [109]. The paradigm shift is also needed from ethnobotanical studies to phytochemical and pharmacological studies. For instance, C. arabica was reported by eight authors, $R$. nepalensis by six authors, $V$. officinalis by five authors, and $V$. sinaiticum by four authors used to treat diarrhoeal diseases in Ethiopia, but no study validated their antidiarrhoeal property by investigating the biological activity of the extracts. Along with phytochemical and pharmacological studies, ethnobotanical studies should also continue, particularly in areas that have received less attention so far. For example, studies should be conducted in the Afar, Benishangul Gumuz, Gambela, Somali, and Tigray regions, like that of Amhara, Oromia, and SNNPR regions (Figure 1).

Almost all ethnobotanical studies conducted in Ethiopia have an objective of documentation of medicinal plants used to treat various diseases including diarrhoea. Early ethnobotanical studies conducted in Ethiopia simply focused on listing the name of medicinal plant species with diseases treated $[45,58,68]$ without providing any detailed information on the medicinal plants in the region. Another concern of ethnobotanical studies conducted in Ethiopia is the number of informants selected to participate in the study. In this regard, many of the studies collected data from 17 to 38 informants $[45,54,58,65,68]$ and concluded the knowledge is accumulated by the respected societies. Surprisingly, one study [45] collected ethnobotanical data from three traditional healers and concluded that the knowledge is acquired by local communities of the study area. These numbers could not be a representative sample size to elucidate the entire knowledge of indigenous people found in a district. Therefore, future ethnobotanical studies in Ethiopia should increase the number of informants to have a representative sample size. This will help to gather sufficient information about medicinal plant species. Many studies also did not compute ranking indices $[23,52,56]$ though they have invaluable advantages in identifying the most preferred (important) medicinal plants in the study area which could aid phytochemical and pharmacological studies in searching of new drugs. Threats and conservation status of medicinal plants $[21,35,54]$ were also overlooked by researchers, though they have advantages to using them sustainably. Ethnobotanical studies should also focus on identifying gender-based and age-based knowledge differences related to medicinal plant uses. In addition, future ethnobotanical studies in Ethiopia should focus on identifying most serious threats to medicinal plants and how local communities manage medicinal plants. Such studies will help in understanding the best conservation strategies and how local communities relate to the plant resources that they use as medicines.

The existing literature shows that there are several plant species having antidiarrhoeal activities. These plants have a lot of potential to be developed as alternatives to the existing drugs. Studies are needed to determine if, for the same active principle and at the same dosage, the efficiency is different for traditional and western remedies [72]. Despite the encouragement of promises shown by these materials, the applications have not been able to transfer from experimental animals' trials to humans and real-life applications; they all remained on papers. One of the drawbacks of the use of traditional medicinal plants for diarrhoeal diseases is the lack of precise dosage which may enhance toxicity [110]. In the assessment of the performance efficiencies of the different plant species as antidiarrhoeal properties, little efforts have been made to evaluate the toxicological effects of the extracts from these plant species. To ameliorate this challenge, attempts should be made to standardize (the drug preparation, dosage, and route of administration) and authenticate plant species which have antidiarrhoeal properties so that they could be used as natural drugs [111]. These efforts will help to produce effective drugs in treating various diarrhoeal diseases. Moreover, establishment of a medicinal plants database with important medicinal uses will have valuable advantages in searching of new drugs.

In searching of new drugs from medicinal plants overexploitation and the Nagoya protocol (2010) should not be overlooked. Overexploitation of medicinal plants especially those found in a restricted geographic location might lead to extinction. For example, C. africana, Cucumis dipsaceus, S. kunthianum, and Withania somnifera which were readily available in Ethiopia are now at the verge of extinction because of overexploitation $[9,54,71]$. Therefore, pharmaceutical companies and research institutions along with local communities should be encouraged to cultivate these medicinal plants to ensure the continuous supply of plant materials [112]. From a governance point of view, Ethiopia requires an 
enforceable policy that protects wild medicinal plants and policy incentives for the cultivation of medicinal plants to reduce overexploitation. Regarding the Nagoya protocol, fair and equitable sharing benefits arising from the utilization of genetic resources and community knowledge must be shared between the people using community knowledge and the people providing them as it is clearly stated in the agreement. If any product is used from the plant species for drug development obtained from indigenous knowledge, the local communities who acquired the knowledge should get benefit.

In order to obtain necessary information for optimum and practical conditions for antidiarrhoeal medicinal plants, there is also a need to investigate the physiological and biochemical functions demonstrated by these plant species. Additionally, identifying the individual bioactive natural products and elucidating the underlying mechanism of the process will have invaluable advantages to use the specific plant species for specific diarrhoeal diseases. Although different active components from various plant species are reported to have antidiarrhoeal activities, availability of similar amounts of those components among different plant species may not result in a similar antidiarrhoeal capabilities. The antidiarrhoeal activities within a single species may also vary depending on the type of climate, soil contents, crop year, and geographical features. Therefore, future phytochemical studies should consider the abovementioned conditions to produce the best out of plant species with antidiarrhoeal properties.

Phytochemical and pharmacological studies should have continued until the end users that experience the problem of diarrhoea. To do this, the dissemination of research findings to the appropriate governmental and nongovernmental agencies, who served as a boundary between the end users and the researchers, is necessary, but lacking. Thus, improvement on this channel of information dissemination shall be of great assistance in the promotion of the plant based antidiarrhoeal drugs to real life applications.

\section{Conclusions}

The study showed a rich diversity of indigenous medicinal plants commonly used for treatment of diarrhoeal diseases in Ethiopia. In this review paper, 132 medicinal plant species are reported that are used in the traditional diarrhoeal treatment by Ethiopian people. Ethnomedicinal research on distribution and usage pattern of antidiarrhoeal plants show variability across geographic and different regions in the country. For instance, sufficient studies were not conducted in the Afar, Benishangul Gumuz, Gambella, and Somali regions. Thus, researches should continue working in these areas that have received less attention. Use pattern of antidiarrhoeal herbal remedies and associated toxicity risks also need to be studied for future application without any doubt of observable side effects. Other challenges that need to be addressed are validation and efficacy of antidiarrhoeal plants. This could be addressed through in vivo and in vitro experiments with consideration to frequently used medicinal plants as to compete with existing conventional drugs. Any drug development needs clinical trials. This is the ultimate procedure to drug development for human or animal use.

\section{Conflicts of Interest}

The authors declare that they have no conflicts of interest.

\section{Acknowledgments}

The authors would like to thank Mr. Tefera Dargie for his support in the preparation of Map of study areas. Mr. Girma Tesfaye also deserves gratitude for improving English of the manuscript.

\section{References}

[1] UNICEF, One is too many ending child deaths from pneumonia and diarrhoea, 2016. https://www.unicef.org/publications/ index_93020.html.

[2] L. Liu, S. Oza, D. Hogan et al., "Global, regional, and national causes of under-5 mortality in 2000-15: an updated systematic analysis with implications for the Sustainable Development Goals," The Lancet, vol. 388, no. 10063, pp. 3027-3035, 2016.

[3] WHO, Guideline for Drinking-Water Quality: Incorporating First Addendum Recommendations, Geneva, 3rd edition, 2011.

[4] WHO, World Health Report, Geneva, 2004.

[5] R. Pankhurst, "An historical examination of traditional Ethiopian medicine and surgery," Ethiopian Medical Journal, vol. 3, pp. 157-172, 1965.

[6] D. Abebe, M. Zewdu, and A. Demissei, "The role of medicinal plants in health care coverage of Ethiopia, the possible integration," in Conservation andSustainable Use of Medicinal Plants in Ethiopia, proceeding of the national work shop, pp. 6-21, 2001.

[7] F. Mesfin, S. Demissew, and T. Teklehaymanot, "An ethnobotanical study of medicinal plants in Wonago Woreda, SNNPR, Ethiopia," Journal of Ethnobiology and Ethnomedicine, vol. 5, no. 28, 2009.

[8] A. Yalew, D. Yared, P. A. Kumar, Z. Tomas, and A. Awol, "Traditional medicinal plants used by people in Libo-Kemkem district," Asian Journal of Agricultural Sciences, vol. 4, no. 3, pp. 171-176, 2012.

[9] M. Megersa, Z. Asfaw, E. Kelbessa, A. Beyene, and B. Woldeab, "An ethnobotanical study of medicinal plants in Wayu Tuka District, East Welega Zone of Oromia Regional State, West Ethiopia," Journal of Ethnobiology and Ethnomedicine, vol. 9, article 68, 2013.

[10] E. A. Palombo, "Phytochemicals from traditional medicinal plants used in the treatment of diarrhoea: modes of action and effects on intestinal function," Phytotherapy Research, vol. 20, no. 9, pp. 717-724, 2006.

[11] S. Umer, A. Tekewe, and N. Kebede, "Antidiarrhoeal and antimicrobial activity of Calpurnia aurea leaf extract," BMC Complementary and Alternative Medicine, vol. 13, no. 21, 2013.

[12] A. B. Asrie, M. Abdelwuhab, Z. Shewamene, D. A. Gelayee, G. M. Adinew, and E. M. Birru, "Antidiarrheal activity of methanolic extract of the root bark of Cordia africana," Journal of Experimental Pharmacology, vol. 8, pp. 53-59, 2016.

[13] E. M. Birru, A. B. Asrie, G. M. Adinew, and A. Tsegaw, "Antidiarrheal activity of crude methanolic root extract of Idigofera spicata Forssk.(Fabaceae)," BMC Complementary and Alternative Medicine, vol. 16, no. 1, article no. 272, 2016. 
[14] N.-U. Rehman, M. H. Mehmood, K. M. Alkharfy, and A.-H. Gilani, "Studies on antidiarrheal and antispasmodic activities of lepidium sativum crude extract in rats," Phytotherapy Research, vol. 26, no. 1, pp. 136-141, 2012.

[15] F. Ching, I. Otokiti, and B. Egert-omoneukanrin, "Dimethoxyflavone isolated from the stem bark of Stereospermum kunthianum possesses antidiarrhoeal activity in rodents," African Journal of Traditional, Complementary and Alternative Medicines, vol. 10, no. 4, pp. 47-51, 2013.

[16] O. Okere, J. Sangodele, O. Tade, O. Obafemi, and J. Falode, "Anti-diarrhea Potential and Acute Toxicity Studies of Methanolic Extract of Vernonia amygdalina and Cymbopogon citratus against Castor Oil Induced Diarrhea Model in Rats," International Journal of Biochemistry Research \& Review, vol. 6, no. 2, pp. 46-52, 2015.

[17] T. Tadesse, E. Hailu, E. Gurmu, and F. Mechesso, "Experimental assessment of antidiarrheal and antisecretory activity of $80 \%$ methanolic leaf extract of Zehneria scabra in mice," BMC Complementary and Alternative Medicine, vol. 14, no. 1, article 460, 2014

[18] T. H. Bekalo, S. D. Woodmatas, and Z. A. Woldemariam, "An ethnobotanical study of medicinal plants used by local people in the lowlands of Konta Special Woreda, southern nations, nationalities and peoples regional state, Ethiopia," Journal of Ethnobiology and Ethnomedicine, vol. 5, article 26, 2009.

[19] M. Giday, Z. Asfaw, and Z. Woldu, "Medicinal plants of the Meinit ethnic group of Ethiopia: an ethnobotanical study," Journal of Ethnopharmacology, vol. 124, no. 3, pp. 513-521, 2009.

[20] B. Kidane, T. van Andel, L. J. G. van der Maesen, and Z. Asfaw, "Use and management of traditional medicinal plants by Maale and Ari ethnic communities in southern Ethiopia," Journal of Ethnobiology and Ethnomedicine, vol. 10, article 46, 2014.

[21] A. Belayneh, Z. Asfaw, S. Demissew, and N. F. Bussa, "Medicinal plants potential and use by pastoral and agro-pastoral communities in Erer Valley of Babile Wereda, Eastern Ethiopia," Journal of Ethnobiology and Ethnomedicine, vol. 8, article 42, 2012.

[22] T. Wondimu, Z. Asfaw, and E. Kelbessa, "Ethnobotanical study of medicinal plants around 'Dheeraa' town, Arsi Zone, Ethiopia," Journal of Ethnopharmacology, vol. 112, no. 1, pp. 152$161,2007$.

[23] M. Giday, Z. Asfaw, Z. Woldu, and T. Teklehaymanot, "Medicinal plant knowledge of the Bench ethnic group of Ethiopia: an ethnobotanical investigation," Journal of Ethnobiology and Ethnomedicine, vol. 5, article 34, 2009.

[24] T. Birhanu, D. Abera, and E. Ejeta, "Ethnobotanical study of medicinal plants in selected Horro Gudurru woredas," Journal of Biology, Agriculture and Healthcare, vol. 5, no. 1, pp. 83-93, 2015.

[25] G. Meaza, B. Tadesse, A. S. Maria, B. Piero, and Y. Gidey, "Traditional medicinal plants used by Kunama ethnic group in Northern Ethiopia," Journal of Medicinal Plants Research, vol. 9, no. 15, pp. 494-509, 2015.

[26] T. Gedif and H.-J. Hahn, "The use of medicinal plants in selfcare in rural central Ethiopia," Journal of Ethnopharmacology, vol. 87, no. 2-3, pp. 155-161, 2003.

[27] G. Seyoum and G. Zerihun, "An ethnobotanical study of medicinal plants in Debre Libanos Wereda, Central Ethiopia," African Journal of Plant Science, vol. 8, no. 7, pp. 366-379, 2014.

[28] Z. Kassa, Z. Asfaw, and S. Demissew, "Ethnobotanical study of medicinal plants used by the local people in Tulu Korma and its surrounding areas of Ejere district, Western Shewa zone of
Oromia regional state, Ethiopia," Journal of Medicinal Plants Studies, vol. 4, no. 2, pp. 24-47, 2016.

[29] B. Abera, "Medicinal plants used in traditional medicine by Oromo people, Ghimbi District, Southwest Ethiopia," Journal of Ethnobiology and Ethnomedicine, vol. 10, no. 1, article 40, 2014.

[30] G. Zenebe, M. Zerihun, and Z. Solomon, "An ethnobotanical study of medicinal plants in Asgede Tsimbila District, Northwestern Tigray, Northern Ethiopia," Ethnobotany Research and Applications, vol. 10, pp. 305-320, 2012.

[31] G. G. Mengesha, "Ethnobotanical survey of medicinal plants used in treating human and livestock health problems," Advancement in Medicinal Plant Research, vol. 4, no. 1, pp. 1126, 2016.

[32] T. Flatie, T. Gedif, K. Asres, and T. Gebre-Mariam, "Ethnomedical survey of Berta ethnic group Assosa Zone, BenishangulGumuz regional state, mid-west Ethiopia," Journal of Ethnobiology and Ethnomedicine, vol. 5, article 14, 2009.

[33] E. Lulekal, Z. Asfaw, E. Kelbessa, and P. Van Damme, "Ethnomedicinal study of plants used for human ailments in Ankober District, North Shewa Zone, Amhara Region, Ethiopia," Journal of Ethnobiology and Ethnomedicine, vol. 9, article 63, 2013.

[34] T. Teklehaymanot, "Ethnobotanical study of knowledge and medicinal plants use by the people in Dek Island in Ethiopia," Journal of Ethnopharmacology, vol. 124, no. 1, pp. 69-78, 2009.

[35] T. Teklehaymanot and M. Giday, "Ethnobotanical study of medicinal plants used by people in Zegie Peninsula, Northwestern Ethiopia," Journal of Ethnobiology and Ethnomedicine, vol. 3, article 12, 2007.

[36] E. Lulekal, E. Kelbessa, T. Bekele, and H. Yineger, "An ethnobotanical study of medicinal plants in Mana Angetu District, southeastern Ethiopia," Journal of Ethnobiology and Ethnomedicine, vol. 4, article 10, 2008.

[37] M. Meragiaw, "Wild useful plants with emphasis on traditional use of medicinal and edible plants by the people of Aba'ala, North-eastern Ethiopia," Journal of Medicinal Plant and Herbal Therapy Research, vol. 4, pp. 1-16, 2016.

[38] E. d'Avigdor, H. Wohlmuth, Z. Asfaw, and T. Awas, “The current status of knowledge of herbal medicine and medicinal plants in Fiche, Ethiopia," Journal of Ethnobiology and Ethnomedicine, vol. 10, no. 1, pp. 38-71, 2014.

[39] G. Gebeyehu, Z. Asfaw, A. Eneyew, and N. Raja, "Ethnobotanical study of traditional medicinal plants and their conservation status in Mecha wereda west Gojjam zone of Ethiopia," International Journal of Pharmaceutical and Health Care Research, vol. 3, no. 2, pp. 137-154, 2014.

[40] A. Teklay, B. Abera, and M. Giday, "An ethnobotanical study of medicinal plants used in Kilte Awulaelo district, Tigray Region of Ethiopia," Journal of Ethnobiology and Ethnomedicine, vol. 9, no. 1, article 65, 2013.

[41] G. Alemayehu, Z. Asfaw, and E. Kelbessa, "Ethnobotanical study of medicinal plants used by local communities of Minjar-Shenkora district, North Shewa zone of Amhara region, Ethiopia," Journal of Medicinal Plants Studies, vol. 3, no. 6, pp. 1-11, 2015.

[42] R. Regassa, T. Bekele, and M. Megersa, "Ethnobotanical study of traditional medicinal plants used to treat human ailments by Halaba people, southern Ethiopia," Journal of Medicinal Plants Studies, vol. 5, no. 4, pp. 36-47, 2017.

[43] G. Chekole, Z. Asfaw, and E. Kelbessa, "Ethnobotanical study of medicinal plants in the environs of Tara-gedam and Amba 
remnant forests of Libo Kemkem District, northwest Ethiopia," Journal of Ethnobiology and Ethnomedicine, vol. 11, no. 4, 2015.

[44] G. Kewessa, T. Abebe, and A. Demessie, "Indigenous knowledge on the use and management of medicinal trees and shrubs in Dale District, Sidama Zone, Southern Ethiopia," Ethnobotany Research and Applications, vol. 14, pp. 171-182, 2015.

[45] G. Yirga, "Use of traditional medicinal plants by indigenous people in mekele town, capital city of tigray regional state of Ethiopia," Journal of Medicinal Plants Research, vol. 4, no. 17, pp. 1799-1804, 2010.

[46] K. Mesfin, G. Tekle, and T. Tesfay, "Ethnobotanical study of traditional medicinal plants used by indigenous people of Gemad district," Journal of Medicinal Plants Studies, vol. 1, no. 4, pp. 32-37, 2013.

[47] A. Issa, Ethnomedicinal study of plants in Jigjigaworeda, eastern Ethiopia [M.S. thesis], Addis Ababa University, 2015.

[48] A. Kefalew, Z. Asfaw, and E. Kelbessa, "Ethnobotany of medicinal plants in Ada'a District, East Shewa Zone of Oromia Regional State, Ethiopia," Journal of Ethnobiology and Ethnomedicine, vol. 11, article 25, 2015.

[49] E. Tolasa, Use, Threat and conservation of traditional medicinal plants by indigenous People in Gimbi woreda, Western Welegga, Ethiopia [M.S. thesis], Addis Ababa University, 2007.

[50] Z. Birhanu, "Traditional use of medicinal plants by the ethnic groups of Gondar Zuria district, North-Western Ethiopia," Journal of Natural Remedies, vol. 13, no. 1, pp. 46-53, 2013.

[51] T. Seifu, Ethnobotanical andethnopharmaceutical studies on medicinal plants ofChifra district, Afar region, north eastern Ethiopia [M.S. thesis], Addis Ababa University, 2004.

[52] G. Bekele and P. R. Reddy, "Ethnobotanical study of medicinal plants used to treat human ailments by Guji Oromo tribes in Abaya district," Universal Journal of Plant Science, vol. 3, no. 1, pp. 1-8, 2015.

[53] E. Andarge, A. Shonga, M. Agize, and A. Tora, "Utilization and conservation of medicinal plants and their associated indigenous knowledge (IK) in Dawuro Zone: An ethnobotanical approach," vol. 4, pp. 330-337, 2015.

[54] M. Giday, T. Teklehaymanot, A. Animut, and Y. Mekonnen, "Medicinal plants of the Shinasha, Agew-awi and Amhara peoples in northwest Ethiopia," Journal of Ethnopharmacology, vol. 110, no. 3, pp. 516-525, 2007.

[55] F. Mesfin, T. Seta, and A. Assefa, "An ethnobotanical study of medicinal plants in Amaro Woreda, Ethiopia," Ethnobotany Research and Applications, vol. 12, pp. 341-354, 2014.

[56] A. Belayneh and N. F. Bussa, "Ethnomedicinal plants used to treat human ailments in the prehistoric place of Harla and Dengego valleys, eastern Ethiopia," Journal of Ethnobiology and Ethnomedicine, vol. 10, article 18, 2014.

[57] M. Tadesse, D. Hunde, and Y. Getachew, "Survey of medicinal plants used to treat human diseases in SekaChekorsa, Jimma Zone, Ethiopia," Ethiopian Journal of Health Sciences, vol. 15, no. 2, pp. 89-107, 2005.

[58] M. Giday, Z. Asfaw, T. Elmqvist, and Z. Woldu, "An ethnobotanical study of medicinal plants used by the Zay people in Ethiopia," Journal of Ethnopharmacology, vol. 85, no. 1, pp. 4352, 2003.

[59] R. Regassa, "Assessment of indigenous knowledge of medicinal plant practice and mode of service delivery in Hawassa city, southern Ethiopia," Journal of Medicinal Plants Research, vol. 7, no. 9, pp. 517-535, 2013.
[60] M. Ragunathan and S. M. Abay, "Ethnomedicinal survey of folk drugs used in Bahirdar Zuria district, Northwestern Ethiopia," Indian Journal of Traditional Knowledge, vol. 8, no. 2, pp. 281284, 2009.

[61] H. Yineger, E. Kelbessa, T. Bekele, and E. Lulekal, "Ethnoveterinary medicinal plants at Bale Mountains National Park, Ethiopia," Journal of Ethnopharmacology, vol. 112, no. 1, pp. 5570, 2007.

[62] K. Tolossa, E. Debela, S. Athanasiadou, A. Tolera, G. Ganga, and J. G. M. Houdijk, "Ethno-medicinal study of plants used for treatment of human and livestock ailments by traditional healers in South Omo, Southern Ethiopia," Journal of Ethnobiology and Ethnomedicine, vol. 9, no. 1, article no. 32, 2013.

[63] E. Amenu, Use and management of medicinal plants by indigenous people ofEjaji area (ChelyaWoreda, WestShoa, Ethiopia. An ethnobotanical approach [M.S. thesis], Addis Addis Ababa University, 2007.

[64] M. Giday, Z. Asfaw, and Z. Woldu, "Ethnomedicinal study of plants used by Sheko ethnic group of Ethiopia," Journal of Ethnopharmacology, vol. 132, no. 1, pp. 75-85, 2010.

[65] M. Meragiaw, Z. Asfaw, and M. Argaw, "The Status of Ethnobotanical Knowledge of Medicinal Plants and the Impacts of Resettlement in Delanta, Northwestern Wello, Northern Ethiopia," Evidence-Based Complementary and Alternative Medicine, vol. 2016, Article ID 5060247, 24 pages, 2016.

[66] M. A. Eshete, E. Kelbessa, and G. Dalle, "Ethnobotanical study of medicinal plants in Guji Agro-pastoralists, Bule Hora district of Borana zone, Oromia region, Ethiopia," Journal of Medicinal Plants Studies, vol. 4, no. 2, pp. 170-184, 2016.

[67] T. Teklehaymanot, M. Giday, G. Medhin, and Y. Mekonnen, "Knowledge and use of medicinal plants by people around Debre Libanos monastery in Ethiopia," Journal of Ethnopharmacology, vol. 111, no. 2, pp. 271-283, 2007.

[68] G. Yirga, "Assessment of traditional medicinal plants in Endrta district, South-eastern Tigray," African Journal of Plant Science, vol. 4, no. 7, pp. 255-260, 2010.

[69] S. Suleman and T. Alemu, "A survey on utilization of ethnomedicinal plants in Nekemte town, East Wellega (Oromia), Ethiopia," Journal of Herbs, Spices \& Medicinal Plants, vol. 18, no. 1, pp. 34-57, 2012.

[70] H. Yineger, D. Yewhalaw, and D. Teketay, "Ethnomedicinal plant knowledge and practice of the Oromo ethnic group in southwestern Ethiopia," Journal of Ethnobiology and Ethnomedicine, vol. 4, article no. 11, 2008.

[71] Z. Birhanu, A. Endale, and Z. Shewamene, "An ethnomedicinal investigation of plants used by traditional healers of Gondar town, North-Western Ethiopia," Journal of Medicinal Plants Studies, vol. 3, no. 2, pp. 36-43, 2015.

[72] Y. Uprety, H. Asselin, A. Dhakal, and N. Julien, “Traditional use of medicinal plants in the boreal forest of Canada: Review and perspectives," Journal of Ethnobiology and Ethnomedicine, vol. 8, article no. 7, 2012.

[73] S. Verma and S. P. Singh, "Current and future status of herbal medicines," Veterinary World, vol. 1, no. 11, pp. 347-350, 2008.

[74] C. W. Wright, "Plant derived antimalarial agents: new leads and challenges," Phytochemistry Reviews, vol. 4, no. 1, pp. 55-61, 2005.

[75] A. L. Otshudi, A. Vercruysse, and A. Foriers, "Contribution to the ethnobotanical, phytochemical and pharmacological studies of traditionally used medicinal plants in the treatment of dysentery and diarrhoea in Lomela area (DRC)," Journal of Ethnopharmacology, vol. 71, no. 3, pp. 411-423, 2000. 
[76] A. Maroyi, "Traditional use of medicinal plants in south-central Zimbabwe: review and perspectives," Journal of Ethnobiology and Ethnomedicne, vol. 9, article 31, 2011.

[77] J. D. Dubreuil, "Antibacterial and antidiarrheal activities of plant products against Enterotoxinogenic Escherichia coli," Toxins, vol. 5, no. 11, pp. 2009-2041, 2013.

[78] G. S. Perez, G. C. Perez, and M. A. Zavala, "A study of the antidiarrhoeal properties of Loeseliamexicanaon mice and rats," Phytomedicine, vol. 12, pp. 670-674, 2005.

[79] R. Fichtl and A. Adi, Honeybee Flora of Ethiopia, Margraf Verlag, 1994.

[80] A. K. Yadav and V. Tangpu, "Antidiarrheal activity of Lithocarpus dealbata and Urena lobata extracts: Therapeutic implications," Pharmaceutical Biology, vol. 45, no. 3, pp. 223-229, 2007.

[81] Y. Kondo, F. Takano, and H. Hojo, "Inhibitory effect of bisbenzylisoquinoline alkaloids on nitric oxide production in activated macrophages," Biochemical Pharmacology, vol. 46, no. 11, pp. 1887-1892, 1993.

[82] P. G. Daswani, S. Brijesh, P. Tetali, N. H. Antia, and T. J. Birdi, "Antidiarrhoeal activity of Zingiber officinale (Rosc.)," Current Science, vol. 98, no. 2, pp. 222-229, 2010.

[83] G. Di Carlo, G. Autore, A. A. Izzo et al., "Inhibition of intestinal motility and secretion by flavonoids in mice and rats: structureactivity relationships," Journal of Pharmacy and Pharmacology, vol. 45, no. 12, pp. 1054-1059, 1993.

[84] A. A. Adedapo, F. O. Jimoh, S. Koduru, A. J. Afolayan, and P. J. Masika, "Antibacterial and antioxidant properties of the methanol extracts of the leaves and stems of Calpurnia aurea," BMC Complementary and Alternative Medicine, vol. 8, article 53, 2008.

[85] S. Edwards, M. Tadesse, and I. Hedberg, Flora of Ethiopia and Eritrea, The National Herbarium, Addis Ababa, Ethiopia, 1995.

[86] B. Abew, S. Sahile, and F. Moges, "In vitro antibacterial activity of leaf extracts of Zehneria scabra and Ricinus communis against Escherichia coli and methicillin resistance Staphylococcus aureus," Asian Pacific Journal of Tropical Biomedicine, vol. 4, no. 10, pp. 816-820, 2014.

[87] A. B. Tesemma, A. Birnie, and B. Tengnas, Useful Trees and Shrubs for Ethiopia, Regional Soil Conservation Unit (RSCU), Swedish International Development Authority (SIDA), 1993.

[88] U. A. Hanwa, A. H. Kaita, M. I. Sule, A. A. Ahmadu, and M. G. Magaji, "Anti-diarrhoeal activity of the leaf extract of Stereopermumkunthianum," Biological and Environmental Sciences Journal for the Tropics, vol. 4, no. 2, 2007.

[89] S. Kothai, "Antimicrobial properties of Ethiopian chewing sticks against Candida albicans," Journal of Applied Pharmaceutical Science, vol. 2, no. 2, pp. 45-50, 2012.

[90] S. Mohammed and K. Tesfaye, "Morphological and Molecular Characterization of Lepidium sativum population collected from Ethiopia," African Journal of Plant Science, vol. 9, no. 4, pp. 215-222, 2015.

[91] D. Manohar, H. Shylaja, G. L. Viswanatha, and S. Rajesh, "Antidiarrhoeal activity of methanolic extracts of Lepidiumsativum in rodent," Journal of Natural Remedies, vol. 9, no. 2, pp. 197-201, 2009.

[92] J. A. Duke, Handbook of Phytochemical Constituents of GRAS Herbs and Other Economic Plants, CRC Press, London, UK, 1992.

[93] T. Fleming, "PDR for Herbal Medicines," in in Medical Economics, pp. 933-934, 393 Company, Montvale, 1998.
[94] A.-H. Gilani, N.-U. Rehman, M. H. Mehmood, and K. M. Alkharfy, "Species differences in the antidiarrheal and antispasmodic activities of lepidium sativum and insight into underlying mechanisms," Phytotherapy Research, vol. 27, no. 7, pp. 1086-1094, 2013.

[95] S. Edwards, M. Tadesse, and I. Hedberg, Flora of Ethiopia and Eritrea, The National Herbarium, Addis Ababa, Ethiopia, 2004.

[96] L. Tona, R. K. Cimanga, K. Mesia et al., "In vitro antiplasmodial activity of extracts and fractions from seven medicinal plants used in the Democratic Republic of Congo," Journal of Ethnopharmacology, vol. 93, no. 1, pp. 27-32, 2004.

[97] M. E. Wall, M. C. Wani, G. Manikumar et al., "Plant antimutagenic agents, 2. Flavonoids," Journal of Natural Products, vol. 51, no. 6, pp. 1084-1091, 1988.

[98] G. Alemayehu, Z. Asfaw, and E. Kelbessa, "Cordia africana (Boraginaceae) in Ethiopia: A review of its taxonomy, distribution, ethnobotany and conservation status," International Journal of Botanical Studies, vol. 1, pp. 38-46, 2016.

[99] R. Regassa, "Diversity and conservation status of some economically valued indigenous medicinal plants in Hawassa College of Teacher Education Campus, Southern Ethiopia," International Journal of Advanced Research, vol. 1, pp. 308-328, 2013.

[100] E. A. Alhadi, H. S. Khalid, M. S. Alhassan, A. S. Kabbashi, and M. O. Noor, "Antimicrobial and phytochemical screening of Cordia africana in Sudan," World Journal of Pharmacy Research, vol. 4, no. 3, pp. 257-269, 2015.

[101] A. I. Isa, M. I. A. Saleh, and A. Abubakar, "Anti-oxidant, anti-inflammatory, anti-bacterial, total phenolic/flavonoids and cytotoxic activities of Cordia africana," Integrative and alternative Medicine, vol. 4, no. 3, 2015.

[102] L. Bueno Pérez, J. Li, D. D. Lantvit et al., "Bioactive constituents of indigofera spicata," Journal of Natural Products, vol. 76, no. 8, pp. 1498-1504, 2013.

[103] M. Fletcher, R. Al Jassim, and A. Cawdell-Smith, "The Occurrence and Toxicity of Indospicine to Grazing Animals," Agriculture, vol. 5, no. 4, pp. 427-440, 2015.

[104] J. H. Pears and M. P. Hegarty, "Indospicine the teratogenic factor from Indigoferaspicata extract causing cleft palate," Journal of Experimental Pathology, vol. 51, no. 34, 1970.

[105] A. Ribeiro, M. M. Romeiras, J. Tavares, and M. T. Faria, "Ethnobotanical survey in Canhane village, district of massingir, mozambique: medicinal plants and traditional knowledge," Journal of Ethnobiology and Ethnomedicine, vol. 6, article 33, 2010.

[106] H. De Wet, M. N. Nkwanyana, and S. F. Van Vuuren, "Medicinal plants used for the treatment of diarrhoea in northern Maputaland, KwaZulu-Natal Province, South Africa," Journal of Ethnopharmacology, vol. 130, no. 2, pp. 284-289, 2010.

[107] N. R. Farnsworth, "Ethnopharmacology and Drug Development," in Ciba Foundation Symposium 185 - Ethnobotany and the Search for New Drugs, Novartis Foundation Symposia, pp. 42-59, John Wiley \& Sons, Ltd., Chichester, UK, 2007.

[108] UNDP, Indigenous peoples, traditional knowledge in forest management key to REDD+ success, 2011. http://www.undp .org/.../undp/.../2011/.../including-indigenous-peoples-a.

[109] I. Vandebroek and M. J. Balick, "Globalization and loss of plant knowledge: Challenging the paradigm," PLoS ONE, vol. 7, no. 5, Article ID e37643, 2012.

[110] A. Sofowora, Medicinal Plants and Traditional Medicine in Africa, John Wiley and Sons, New York, NY, USA, 3rd edition, 2008. 
[111] C. D. Kumar, "Pharmacognosy can help minimize accidental misuse of herbal medicine," Current Science, vol. 93, no. 10, pp. 1356-1358, 2007.

[112] C. Njume and N. I. Goduka, "Treatment of diarrhoea in rural African communities: An overview of measures to maximise the medicinal potentials of indigenous plants," International Journal of Environmental Research and Public Health, vol. 9, no. 11, pp. 3911-3933, 2012. 


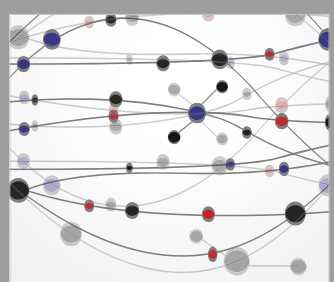

The Scientific World Journal
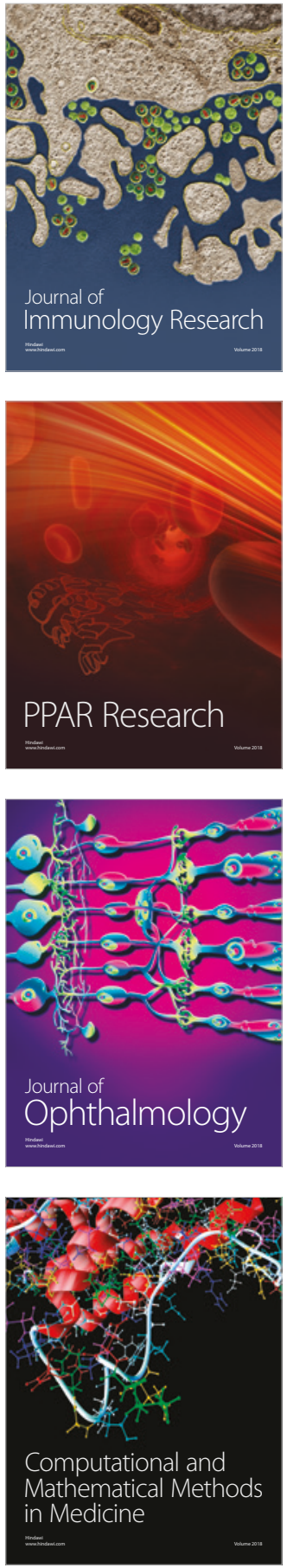

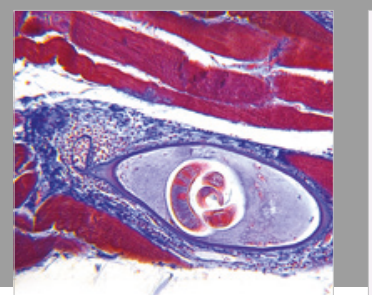

Gastroenterology Research and Practice

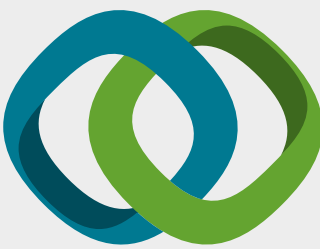

\section{Hindawi}

Submit your manuscripts at

www.hindawi.com
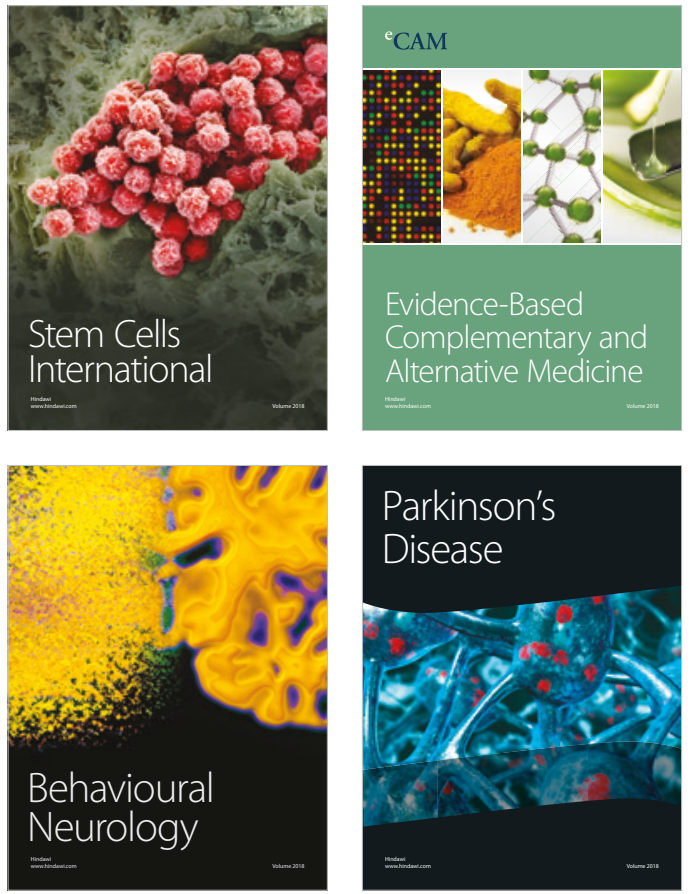

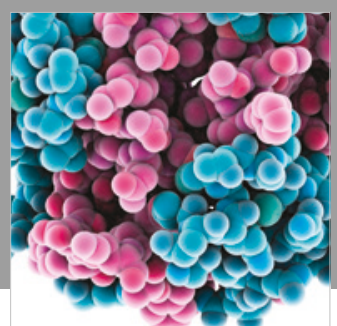

ournal of

Diabetes Research

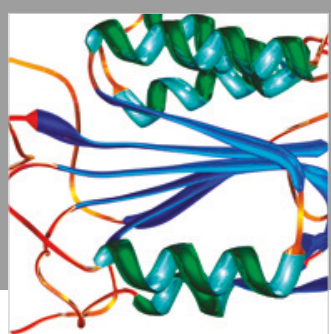

Disease Markers
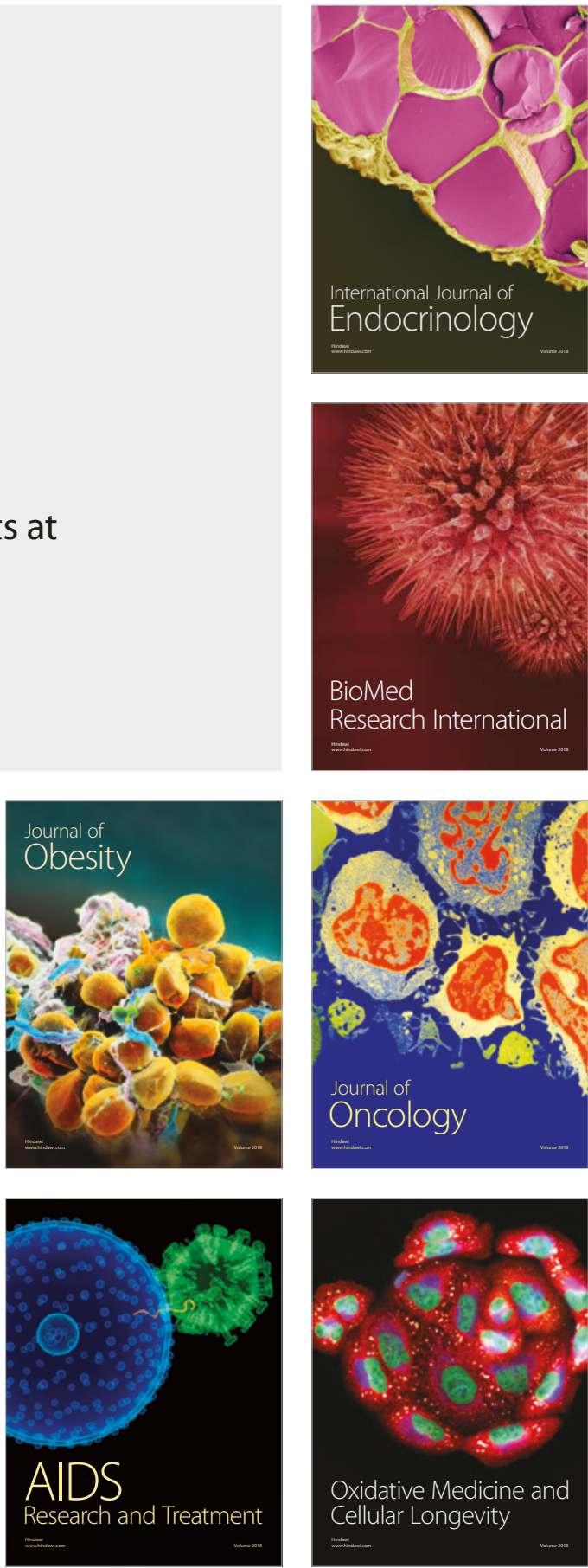